УДК [378.091:656.7]:004

Тимошенко Ганна Сергіївна

старша викладачка кафедри інформаційних технологій

Льотна академія Національного авіаційного університету, м. Кропивницький, Україна

ORCID ID 0000-0003-2411-497X

jaanti@ukr.net

Данилко Оксана Григорівна

кандидат педагогічних наук, доцент кафедри інформаційних технологій

Льотна академія Національного авіаційного університету, м. Кропивницький, Україна

ORCID ID 0000-0002-7942-8012

monyasolnce@gmail.com

Сагановська Лариса Анатоліївна

старша викладачка кафедри інформаційних технологій

Льотна академія Національного авіаційного університету, м. Кропивницький, Україна

ORCID ID 0000-0002-2560-4383

lora-sag@ukr.net

\title{
РОЗРОБКА ТА ВИКОРИСТАННЯ ЕЛЕКТРОННОГО ЛАБОРАТОРНОГО ПРАКТИКУМУ «ПЛАН ПОЛЬОТУ» ДЛЯ ПІДГОТОВКИ ДИСПЕТЧЕРІВ ІЗ ЗАБЕЗПЕЧЕННЯ ПОЛЬОТІВ
}

\begin{abstract}
Анотація. Стаття присвячена розробці електронного лабораторного практикуму «План польоту». Авторами розглянуто питання щодо доцільності та ефективності введення електронних засобів навчання в освітній процес, оскільки в авіаційному середовищі існує потреба в удосконаленні існуючих та створенні нових електронних засобів навчання у сфері планування польотів і забезпечення екіпажів повітряних суден необхідною інформацією. У процесі дослідження встановлено, що не існує електронних лабораторних практикумів 3 планування польотів для підготовки майбутніх диспетчерів із забезпечення польотів. Виділено етапи створення та застосування електронних засобів навчання. На етапі проєктування та розробки практикуму створено алгоритм імітації професійної діяльності диспетчера із забезпечення польотів, побудовано структурну схему процесу навчання майбутніх фахівців, що має бути реалізована в лабораторному практикумі. У результаті системного аналізу сформульовано вимоги до електронного лабораторного практикуму «План польоту», представлено схему реалізації компонентів практикуму, а також безпосередньо розроблено інтерфейс електронного засобу навчання «План польоту» 3 описом усіх його функцій та можливостей. У ході експериментального дослідження, що проводилось на базі Льотної академії Національного авіаційного університету виконано оцінку реалізованих функцій практикуму за техніко-технологічним, психологопедагогічним та дизайн-критерієм. Зроблено висновок щодо доцільності використання електронного лабораторного практикуму 3 планування польотів у навчальному процесі, оскільки розроблений електронний засіб навчання дозволяє імітувати професійну діяльність диспетчерів із забезпечення польотів у різних умовах, дає змогу отримати теоретичні знання та набути практичного досвіду з обраної теми, а отже, підвищити якість професійної підготовки авіаційних фахівців.
\end{abstract}

Ключові слова: диспетчер із забезпечення польотів; планування польотів; електронні засоби навчання; електронний лабораторний практикум.

\section{1. ВСТУП}

Одним із головних завдань при підготовці авіаційних фахівців на сучасному етапі розвитку суспільства $є$ підготовка молодого покоління до швидкого сприйняття й опрацювання великих обсягів даних, озброєння новітніми засобами та технологіями роботи. Диспетчерська робота є одним з найбільш складних і відповідальних видів 
діяльності, оскільки вона висуває високі вимоги до людини-оператора. Для цієї роботи характерна висока ймовірність виникнення екстремальних ситуацій, що вимагають швидкого й грамотного прийняття рішень.

Підготовка майбутніх диспетчерів із забезпечення польотів (ЗП) передбачає засвоєння курсантами системи професійних знань, формування професійних умінь $\mathrm{i}$ творчих здібностей, уміння швидко адаптуватися до умов, які швидко змінюються, i переорієнтуватись $з$ одного виду діяльності на інший. До обов'язків диспетчерів із забезпечення польотів входить звільнення командира повітряного судна (ПС) від рутинної роботи та надання йому інформації й консультації (брифінг), а також сприяння безпечному виконанню польотів.

Саме тому диспетчер із забезпечення польотів повинен розуміти i визначати пріоритети відповідної інформації, а також уміти планувати майбутню діяльність, своєчасно приймати необхідні рішення, виконувати та забезпечувати їх дотримання.

Після дослідження професійної діяльності диспетчера із забезпечення польотів та проведення опитування авіаційних спеціалістів, які працюють із відомостями по забезпеченню польотів, були виявлені наступні помилки: несвоєчасне надання планів польотів в інтегровану систему первинної обробки планів польотів IFPS; неповна та неправильна передача екіпажу перед вильотом необхідних інструкцій та документів для виконання польоту; використання застарілих баз даних у програмах планування тощо [1]. Зрозуміло, що помилкові дії диспетчера із забезпечення польотів відбуваються з різних причин, що можна зарахувати до факторів навчання, особистих факторів тощо.

Постановка проблеми. Однією 3 причин виникнення помилкових дій диспетчерів із забезпечення польотів можна вважати недостатній рівень їх професійної підготовки, а отже, дослідження, пов'язані з цим напрямом, мають актуальний характер i можуть значною мірою сприяти підвищенню рівня безпеки польотів. Змістовне наповнення професійної підготовки повинно конструюватись у такий спосіб, щоб забезпечити не лише ефективну передачу навчального матеріалу, а й сформувати у курсантів здатність найбільш ефективно використовувати цю інформацію у своїй практичній діяльності. Тому одним із напрямків підвищення рівня професійної підготовки майбутніх диспетчерів із забезпечення польотів ми вбачаємо у вдосконаленні електронних засобів навчального процесу шляхом розробки та використання в навчальному процесі електронного лабораторного практикуму «План польоту».

Аналіз останніх досліджень і публікацій. В останні роки проблема створення та використання електронних засобів навчання 3 метою підвищення якості професійної підготовки майбутніх фахівців набула особливої ваги. Зокрема питання щодо розвитку теоретичних основ інформатизації освіти та практичної реалізації інформаційнокомунікаційних технологій в освітній сфері висвітлено в роботах таких вітчизняних та зарубіжних учених, як-от: В. Ю. Бикова [2], О.Ю.Бурова [3], М. П. Шишкіної [4], А. Грея [5], Б. Пернісі [6] та ін.. Сутнісні характеристики електронних підручників, дидактичні аспекти їх створення і використання вивчалися М. І. Жалдаком [7], В. Мадзігоном [8], Г. П. Лаврентьєвою [9] тощо.

Так, аналізуючи наукову літературу за тематикою дослідження [9], було встановлено, що існує багато підходів до введення термінів і понять, які описують інформатизацію навчання. У багатьох наукових і навчально-методичних виданнях їх називають педагогічними програмними засобами, комп'ютерними навчальними засобами, педагогічними засобами навчального призначення, навчальними комп'ютерними програмами. У межах цього дослідження для найменування засобів, що працюють із залученням комп'ютерної техніки і застосованих безпосередньо в навчанні 
учнів, використаний термін «електронний засіб навчання» $(\mathrm{E} 3 \mathrm{H})$ як одна зі складових інформаційно-освітнього середовища навчання.

Проблемам професійної підготовки майбутніх авіаційних фахівців присвячено праці таких науковців: Т. Ф. Шмельової та Ю. В. Сікірди [10], Р. М. Макарова [11], К. В. Суркової [1] та інших. Наукові дослідження, пов'язані із безпекою польотів, знаходять відображення в роботах дослідників О. М. Реви [12], Т. Ф. Шмельової [10], П. Ш. Мухтарова [13], Р. Абейратне [14] тощо, а також регламентуючих документах IКАО (Міжнародна організація цивільної авіації) та документах аеронавігаційної інформації [15].

Метою статті $\epsilon$ поетапна розробка електронного лабораторного практикуму 3 планування польотів для імітації професійної діяльності диспетчерів із забезпечення польотів у різних умовах та наближення електронних засобів навчання до існуючих професійних автоматизованих систем, що використовуються в цивільній авіації.

\section{2. ТЕОРЕТИЧНІ ОСНОВИ ДОСЛІДЖЕННЯ}

Використовуючи сучасні інформаційні технології, диспетчери із забезпечення польотів здійснюють контроль та забезпечення рейсів, що виконують польоти з різних частин земної кулі; ведуть зв'язок, отримують і відправляють повідомлення літакам, що здійснюють політ над Тихим і Атлантичним океанами або за полярними маршрутами, про зміни метеорологічних умов в аеропортах призначення, запасних та за маршрутом польоту, зміну аеронавігаційних даних, а також іншу інформацію, що може вплинути на безпечне завершення рейсу.

Уся необхідна інформація для безпечного та ефективного виконання всього рейсу знаходиться у диспетчера із ЗП, і лише він може надати відповідну консультацію й допомогу екіпажу ПС у процесі виконання польоту як у звичайних, так i в екстремальних умовах діяльності.

Функції, що виконуються фахівцями, які забезпечують та контролюють виконання польотів, у міжнародній практиці поділяють на три складові [16]:

- забезпечення (або планування) польотів;

- контроль за виконанням польотів;

- сприяння екіпажу у виконанні рейсу.

У професійні обов'язки диспетчерів із ЗП входить велика кількість функцій i завдань, які необхідно виконати швидко, впевнено і 3 необхідною точністю. Диспетчери 3 забезпечення польотів користуються всією необхідною інформацією, тобто знаннями, уміннями і навичками, отриманими в результаті навчання, які можуть знадобитись у процесі реальної професійної діяльності, що обумовлює необхідність удосконалення професійної підготовки, зокрема вдосконалення засобів навчання.

Збільшення обсягів інформації, вимог до професійної підготовки диспетчерів із забезпечення польотів й обмеженість навчального часу зумовлюють необхідність інтенсифікації навчання, розробки та впровадження нетрадиційних технологій, що базуються на використанні інформаційних технологій із залученням електронних засобів навчання.

Основними видами комп'ютерних засобів навчального призначення, які можуть розглядатися як компоненти ЕЗН, є [17]:

- сервісні програмні засоби загального призначення;

- програмні засоби для контролю i виміру рівня знань, умінь i навичок курсантів;

- електронні тренажери;

- програмні засоби для математичного та імітаційного моделювання; 
- програмні засоби лабораторій віддаленого доступу та віртуальних лабораторій;

- інформаційно-пошукові довідкові системи;

- автоматизовані навчальні системи;

- електронні підручники;

- експертні навчальні системи;

- інтелектуальні навчальні системи;

- засоби автоматизації професійної діяльності (промислові системи або їх навчальні аналоги).

На думку М. І. Бєляєва, .В.Гріншкуна, Г. А. Краснової [17], поняття електронного засобу навчання можна ототожнювати 3 поняттям освітнього електронного видання, а також електронного навчального видання. У такому разі можлива наступна, на наш погляд, найбільш загальна класифікація ЕЗН [18]:

За функціональною ознакою, що визначає значення i місце в навчальному процесі:

1) програмно-методичні (навчальні плани і навчальні програми);

2) навчально-методичні (методичні вказівки, керівництва, що містять матеріали 3 методики викладання навчальної дисципліни, вивчення курсу, виконання курсових i дипломних робіт);

3) навчальні (підручники, навчальні посібники, тексти лекцій, конспекти лекцій);

4) допоміжні (практикуми, збірники завдань і вправ, хрестоматії, книги для читання);

5) контролюючі електронні навчальні видання, до яких належать програми для тестування і бази даних.

За структурою:

1) однотомні (випущені на одному носіі);

2) багатотомні (що складаються з двох або більше пронумерованих частин, кожна з яких представлена на окремому машиночитаному носії, які становлять єдине ціле по змісту та оформленню);

3) серійні електронні видання (сукупність томів, об'єднаних спільністю задуму, тематики, цільовим призначенням, що виходять в однотипному оформленні).

За характером представленої інформації (навчальний план, навчальна програма, методичні вказівки, методичні керівництва, програми практик, завдання для практичних занять, підручник, навчальний посібник, конспект лекцій, курс лекцій, практикум, хрестоматія, книга для читання).

За формою викладу матеріалу (конвекційні (реалізують інформаційну функцію навчання), програмовані (створені за допомогою засобів програмування), проблемні (базуються на теорії проблемного навчання і спрямовані на розвиток логічного мислення) і комбіновані, або універсальні (містять окремі елементи перерахованих моделей)) .

За цільовим призначенням (для школярів, для бакалаврів, для дипломованих фахівців, для магістрів, для дорослих).

За наявністю друкарського еквіваленту (електронний аналог друкованого навчального видання - електронне навчальне видання в основному відтворює відповідне друковане видання (розташування тексту на сторінках, ілюстрації, посилання, примітки тощо); самостійне електронне навчальне видання - електронне видання, що не має друкованих аналогів).

За природою основної інформації:

1) текстове (символьне) - електронне видання, що містить переважно текстову інформацію, представлену у формі, що допускає посимвольну обробку; 
2) образотворче - електронне видання, що містить переважно електронні зразки об'єктів, що розглядаються як цілісні графічні суті, представлені у формі, що допускає перегляд і друковане відтворення, але не допускає посимвольної обробки;

3) звукове - електронне видання, що містить цифрове представлення звукової інформації у формі, що допускає іiі прослуховування, але не призначеної для друкованого відтворення;

4) програмний продукт - самостійний твір, що являє собою публікацію тексту програми або програм на мові програмування або у вигляді виконуваного коду;

5) мультимедійне - електронне видання, у якому інформація різної природи присутня рівноправно й взаємопов'язано для вирішення розробником певних завдань, причому цей взаємозв'язок забезпечений відповідними програмними засобами.

За технологією розповсюдження:

1) локальне електронне видання, призначене для локального використання i випускається у вигляді певної кількості ідентичних екземплярів (тиражу) на переноситься на машиночитаних носіях;

2) мережне електронне видання, доступне потенційно необмеженому колу користувачів через телекомунікаційні мережі;

3) електронне видання комбінованого розповсюдження, яке може використовуватися як у якості локального, так і в якості мережевого.

За характером взаємодії користувача і електронного видання:

1) детерміноване електронне видання (параметри, зміст і спосіб взаємодії з яким визначені видавцем і не можуть бути змінювані користувачем);

2) недетерміноване електронне видання (параметри, зміст і спосіб взаємодії 3 яким безпосередньо чи опосередковано встановлюються користувачем відповідно до його інтересів, мети, рівня підготовки і т.д. на основі інформації та за допомогою алгоритмів, визначених видавцем).

Сучасний навчальний мультимедіакурс характеризується не просто як інтерактивний текстовий (або навіть гіпертекстовий) матеріал, доповнений відео і аудіоматеріалами і представлений в електронному вигляді. У його структурі [19]: електронний підручник, електронний довідник, тренажерний комплекс (комп'ютерні моделі, конструктори й тренажери), задачник, електронний лабораторний практикум, комп'ютерна система для тестування.

Водночас електронний лабораторний практикум (ЕЛП) є важливою складовою професійної підготовки майбутніх авіаційних фахівців, оскільки у ході роботи 3 практикумами курсанти закріплюють теоретичні знання практичною роботою та набувають дослідницьких умінь і навичок.

Проведенням лабораторного практикуму з курсантами досягаються наступні цілі:

- поглиблення та закріплення знання теоретичного курсу шляхом практичного вивчення в лабораторних умовах викладених у лекції законів і положень;

- набуття навичок у науковому експериментуванні, аналізі отриманих результатів;

- практичне ознайомлення з вимірювальною апаратурою та методами роботи на ній;

- формування первинних навичок організації, планування та проведення наукових досліджень [20].

Крім того, використання ЕЛП у навчальному процесі дозволяє вирішити такі нагальні проблеми, як-от: економія коштів, що витрачаються на лабораторне устаткування, скорочення часу на підготовку й проведення лабораторних робіт тощо.

У ході аналізу відомих ЕЛП 3 дисциплін, що вивчаються майбутніми диспетчерами із ЗП, виявлено, що ЕЛП 3 підготовки майбутніх диспетчерів із 
забезпечення польотів не існує, тому було вирішено розробити ЕЛП «План польоту (ПП)».

Даний ЕЛП виступає засобом імітації діяльності диспетчера із забезпечення польотів при складанні й відправленні плану польоту та призначений для здобуття майбутніми фахівцями основних понять щодо здійснення ефективної діяльності авіакомпанії, формування навичок і вмінь при складанні планів польоту.

ЕЛП «План польоту» - один із засобів формування професійної надійності диспетчерів із забезпечення польотів, що визначає здатність вирішувати професійні проблеми, які виникають у ситуаціях реальної діяльності авіакомпанії. Він має інформаційний характер, активізує пізнавальну діяльність курсантів, містить проблемні запитання і завдання по ПП згідно із встановленими вимогами, здійснює планування діяльності курсантів у межах навчальної теми, отримання запитів, заповнення бланку плану польоту (FPL). ЕЛП «План польоту» видає результати проведення вправ самоконтролю, тестових, контрольних вправ, що дозволяє виявити труднощі, які виникають у навчанні, провести діагностику навчання. Практикум складається 3 теоретичної частини, де можна ознайомитись з навчальним матеріалом і довідковими відомостями, а також практичної частини, де теоретичні знання будуть закріплені за допомогою вправ самоконтролю та тестових вправ діагностики.

Звернення саме до ЕЛП як електронного засобу навчання в даному дослідженні обумовлено наступними причинами:

- можливістю індивідуалізувати роботу курсантів;

- наявністю зворотного зв'язку, що дозволяє коригувати роботу курсантів у ході навчального процесу;

- можливістю збору статистичної інформації на всіх стадіях навчального процесу;

- можливістю накопичення та швидкої корекції навчальних матеріалів;

- наявністю інструментарію для управління банком навчальних матеріалів, що забезпечують зручну роботу з даними;

- оптимізацією праці викладача.

\section{3. РЕЗУЛЬТАТИ ДОСЛІДЖЕННЯ}

Процес створення і застосування електронних засобів навчання складається 3 п'яти основних етапів [17, 21] (Рис.1).

Насамперед, етап аналізу пов'язаний з осмисленням тих завдань, які належить розв'язувати майбутньому ЕЛП 3 планування польотів, i формуванням вимог. Предметною областю називають частину реального світу (клас чи сукупність класів реальних об'єктів), що підлягає модельному відображенню з метою іï вивчення під деяким визначеним кутом зору, який також входить у поняття предметної області [22].

Системний аналіз предметної області передбачає [23] мовний опис реальних об’єктів предметної області, визначення зв'язків між об'єктами, дослідження характеристик об'єктів і зв'язків. Предметною областю, яка підлягає автоматизації, у нашому дослідженні є процес навчання майбутніх диспетчерів із ЗП складанню планів польоту, а також професійне середовище таких фахівців.

Вимоги, представлені в [24], класифікуються на загальні, педагогічні і методичні. Структура практикуму повинна мати складові, що забезпечують можливість ефективного досягнення навчально-виховних цілей, i, залежно від функціонального призначення, може містити:

Складові змістовної частини:

- зміст; теоретична i практична частини; робоче середовище, зокрема інтерактивні моделі; 
- малюнки (схеми, діаграми, графіки, карти, таблиці ін.);

- фотографії;

- відеофрагменти;

- звукові ряди декількома мовами;

- 2D і 3D анімації;

- словник термінів і понять (глосарій), тезаурус, показники;

- предметні і міжпредметні довідники;

- історичні довідки;

- список джерел інформації;

- контрольні запитання та завдання;

- тестові завдання для поточного, тематичного і контрольного оцінювання.

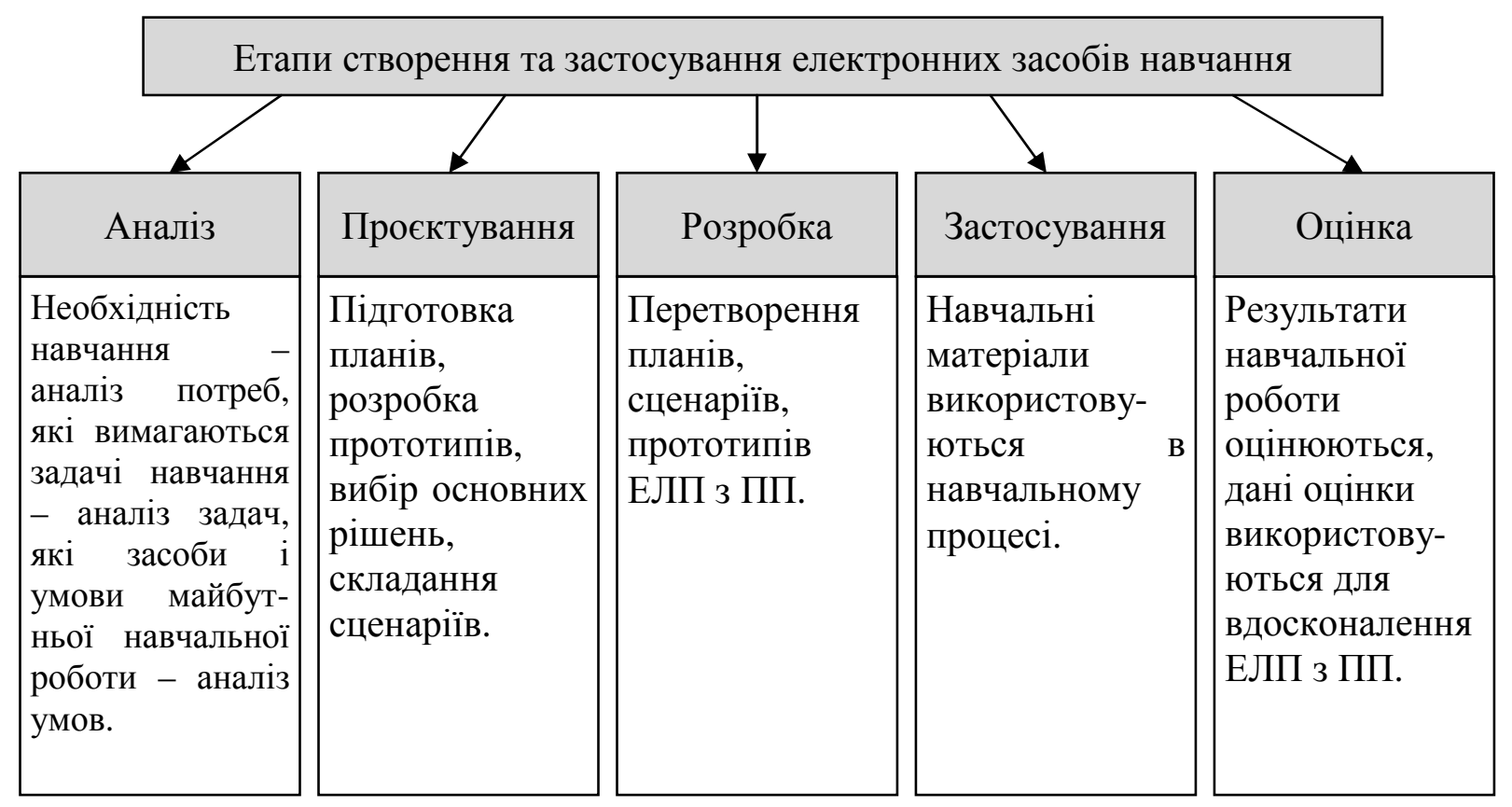

Рис.1. Етапи створення та застосування електронних засобів навчання

Засоби програмної частини:

- засоби для відображення змістовної частини (разом з текстами, медіаоб'єктами, завданнями в текстовій формі) і здійснення навігації по програмному забезпеченню;

- засоби пошуку теоретичного матеріалу;

- засоби для роботи із закладками;

- програмно-методичне забезпечення для підготовки, обробки, передачі та відображення статистичних відомостей про рівень навчальних досягнень і результати тестування студентів;

- конструктор заняття (уроку), який дозволяє сконструювати заняття (урок) за планом, обраним викладачем.

Конструктор заняття (уроку) повинен забезпечувати:

- створення окремих екранів (сторінок), створення нових занять (уроків), додавання до заняття (уроку) або можливість прибрати з заняття (уроку) окремих екранів (сторінок);

- додавання (створення) або видалення існуючих тестів і завдань (створення тестів і завдань із зазначенням правильних/неправильних відповідей i формування автоматичної реакції при виконанні тестів і завдань студентами); 
- інтегроване застосування всіх засобів конструктора для створення окремих екранів (кроків), занять (уроків) і навчального курсу в цілому;

- форматування графічної інформації (зміна розмірів об'єктів, розміщення на екрані і взаємне розташування декількох об'єктів);

- формування текстової інформації: наявність зручних засобів для введення i формування тексту, форматування абзаців, написання формул, робота зі стандартними графічними засобами, ін.;

- гнучкість маршрутів проходження навчального матеріалу i можливість призначення траєкторій;

- імпорт, експорт створеного заняття (уроку) або певного медіаоб'єкту;

- функцію збереження створеного заняття (уроку) після виходу з конструктора.

Проєктування і розробка ЕЛП з планування польотів проходило поетапно: аналіз предметної області (ПО), формулювання і аналіз вимог, інфологічне моделювання, даталогічне проєктування, апробація, доопрацювання.

У першу чергу проводився змістовний аналіз предметної області, виявлені основні поняття процесу навчання зі складання плану польоту та їх взаємозв'язки, визначені необхідні завдання і способи їх вирішення, а також на першому етапі сформульовані вимоги до розроблюваного практикуму. Цей етап завершився створенням моделі, що містить основні концепти і відношення.

На етапі проєктування визначали наступні компоненти: типи доступних даних; вхідні і вихідні дані; підзадачі загальної задачі; види взаємозв'язків між об'єктами предметної області; процеси, що використовуються в ході вирішення; склад знань, що використовуються при виконанні завдань; типи обмежень, накладених на процеси, що використовуються в ході виконання завдань; склад знань, використовуваних для обгрунтування виконання завдань.

Обслуговування повітряного руху неможливе без планування польотів повітряних суден. Планування повітряного руху в загальному випадку являє собою розробку i реалізацію сукупності заходів, спрямованих на збір і обробку інформації про характер передбачуваного повітряного руху з метою приведення у відповідність потреб у повітряному русі 3 пропускною здатністю елементів системи обслуговування повітряного руху (ОПР) і створення умов, що забезпечують безпеку та технікоекономічну ефективність польотів. Ця мета досягається необхідною організацією планування повітряного руху, в основу якої покладено ряд загальносистемних принципів, що конкретизуються з урахуванням специфічних особливостей реалізації процесів планування.

Залежно від тривалості інтервалу часу, на який здійснюється планування повітряного руху, застосовують такі види планування: довгострокове (перспективне); добове; поточне. Реалізація кожного з них повинна враховувати цілий ряд специфічних характеристик, що властиві системі ОПР і визначаються залежно від цілей і завдань, розв'язуваних у процесі планування. Поточне планування польотів здійснюється в аеропортах з підвищеною інтенсивністю польотів та полягає в погодинному плануванні 3 метою уникнення перевантаження зон ОПР та аеродромів, повітряних суден, що прибувають та відлітають. Поточне планування є перехідним етапом до безперервного планування польотів та спрямоване на підвищення безпеки, регулярності та інтенсивності польотів. Поточне планування здійснюється на підставі подання плану польоту - FPL.

3 метою імітації професійної діяльності диспетчера із забезпечення польотів в ЕЛП з ПП необхідно розробити алгоритм (Рис 2.).

Бланк плану польоту представляє собою узгоджений країнами-членами IKАО документ, що має стандартний вигляд. Зразок формату та порядок його заповнення 
розміщуються в документі IKAO - Dос. 4444 «Організація повітряного руху» [ 25]. Типи польотів, при яких необхідно подавати план польоту, також узгоджені в міжнародному масштабі та викладені в Додатку 2 «Правила польотів» до Чикагської Конвенції [26].

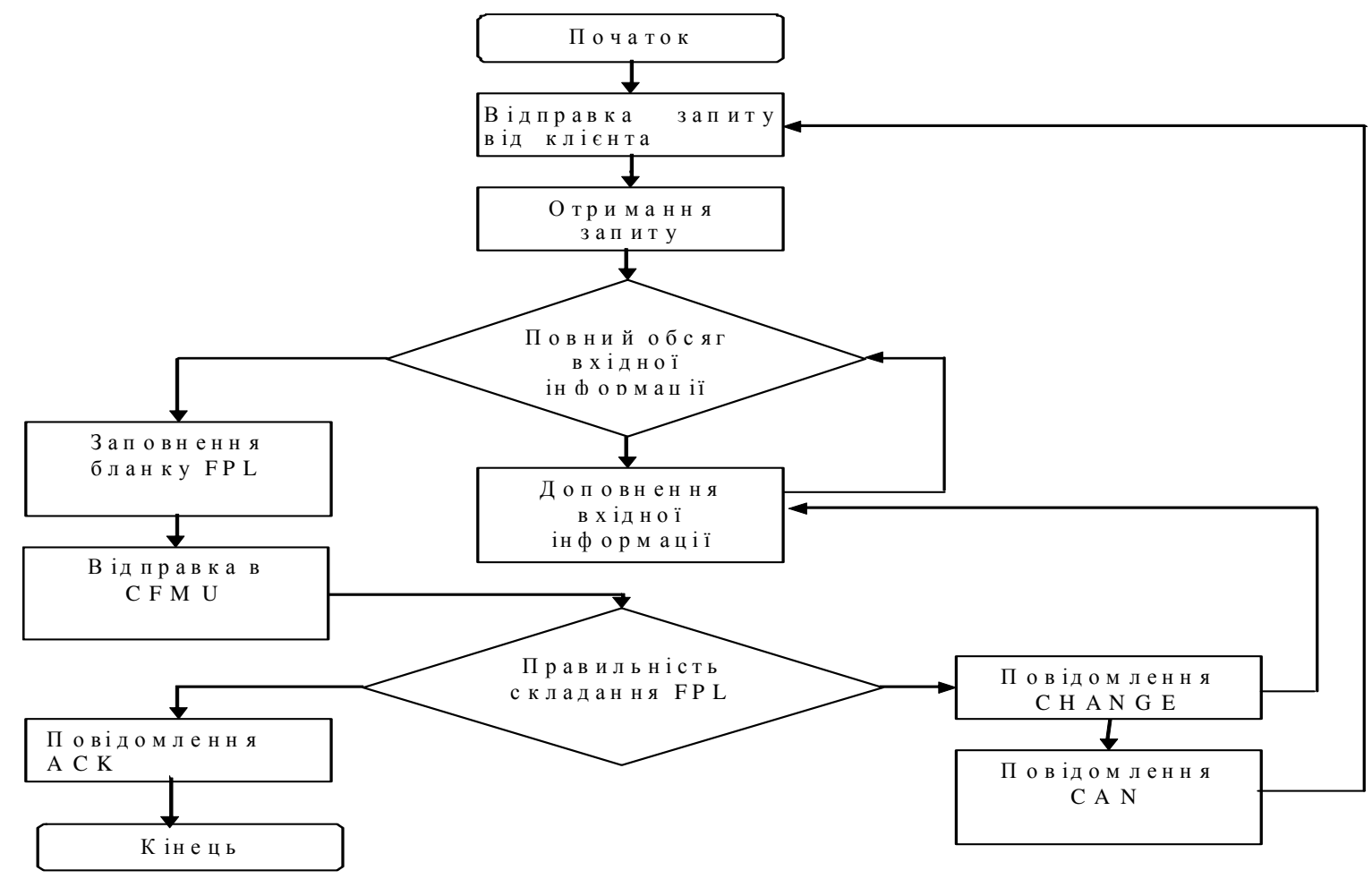

Рис. 2. Алгоритм професійної діяльності диспетчера із забезпечення польотів при складанні плану польоту

Процес навчання майбутніх диспетчерів із забезпечення польотів, що буде реалізований в ЕЛП з планування польотів, представлений на Рис.3.

Що стосується вимог до програмного засобу, то їх можна розділити на такі групи:

- вимоги до виробу (системи) в цілому;

- вимоги до окремих видів забезпечення;

- вимоги до окремих підсистем або модулів;

- вимоги до окремих функцій;

- організаційні вимоги;

- зовнішні вимоги, що характеризують предметну область (навколишнє середовище) [27].

За класифікацією [28] серед вимог до програмного продукту виокремлюють функціональні та нефункціональні вимоги.

Функціональні вимоги визначають поведінку програмного виробу: це перелік дій i функцій, що повинні бути реалізовані. Не функціональні вимоги не пов'язані безпосередньо 3 функціями, виконуваними системою. Вони пов'язані 3 такими інтеграційними властивостями системи, як надійність, час відповіді, розмір системи та iH. 


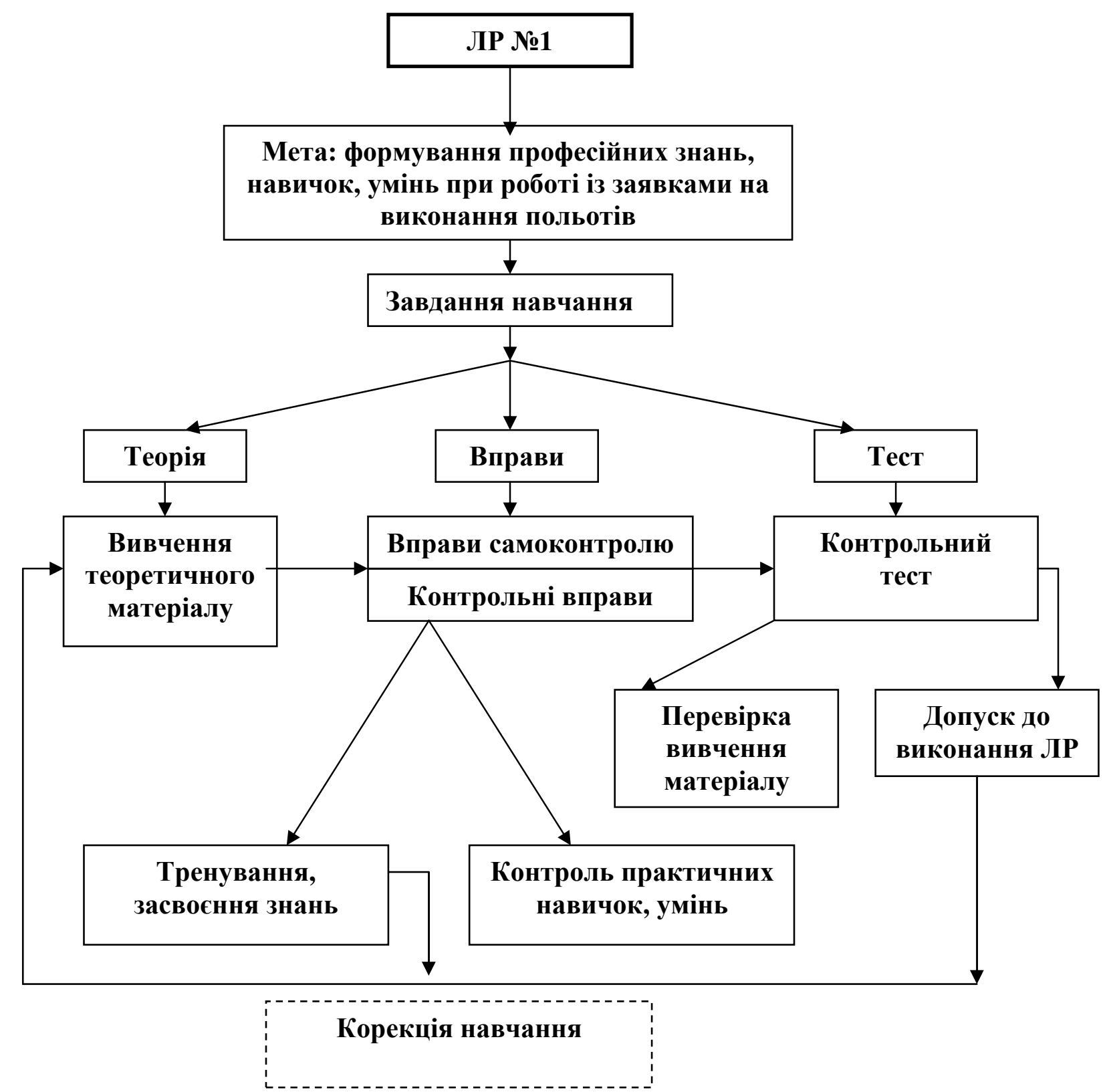

Рис. 3. Прочес навчання, реалізований в електронному лабораторному практикумі з планування польотів

У результаті системного аналізу програмного засобу (ПЗ) сформовані функціональні вимоги до ЕЛП «План польоту»:

- інформація, яка повинна зберігатися в ЕЛП: приклад бланку плану польоту FPL; приклад заповненого FPL; методичні рекомендації до виконання лабораторної роботи; вправи самоконтролю; контрольні вправи; назви документів аеронавігаційної інформації, необхідних для заповнення FPL; маршрутні карти; інструкція для користувачів; поля FPL;

- завдання до вправ самоконтролю та контролю щодо заповнення FPL мають містити точно вказані маршрут польоту (пункт вильоту та призначення), час і дату виконання рейсу, тип ПС, крейсерську швидкість, ешелон польоту;

- має бути передбачено вхідне та контрольне тестування знань теоретичного матеріалу по складанню FPL;

- формування навичок і вмінь заповнення FPL у курсантів, контроль заповнення; 
- забезпечення функцій запуску і закінчення роботи; забезпечення доступу до навчального матеріалу; навігація по навчальному матеріалу; подання навчального матеріалу та забезпечення взаємодії з ним;

- забезпечення моделювання професійної діяльності диспетчерів із забезпечення польотів;

- виконання самоконтролю та контролю знань;

- забезпечення виконання службових функцій.

Нефункціональні вимоги до розроблюваного ЕЛП «План польоту»:

- забезпечення захисту інформації від несанкціонованого доступу, надання інструкцій для користувачів, розмежування прав доступу користувачів до функцій i компонентів ЕЛП, демонстрація основних можливостей і прийомів роботи;

- забезпечення доступу до всіх необхідних користувацьких файлів;

- забезпечення подальшого вдосконалення та змін ЕЛП;

- виконання вимог збереження цілісності даних, обмеженості доступу до них.

У результаті аналізу компонентів програмного засобу (процесу навчання майбутніх диспетчерів із забезпечення польотів та професійної діяльності таких фахівців) було визначено мету та завдання навчання, що реалізуються в розробленому ЕЛП «План польоту».

Мета навчання: формування професійних знань, умінь та навичок у майбутніх диспетчерів із ЗП при складанні плану польоту.

Завдання навчання для курсантів:

- вивчити та закріпити основні поняття та визначення, що використовуються при складанні плану польоту;

- навчитися працювати з документами та збірниками аеронавігаційної інформації, аеронавігаційними картами, регламентуючими документами тощо;

- навчитися правильно складати план польоту.

Реалізація компонентів електронного лабораторного практикуму з планування польотів представлена на Рис. 4.

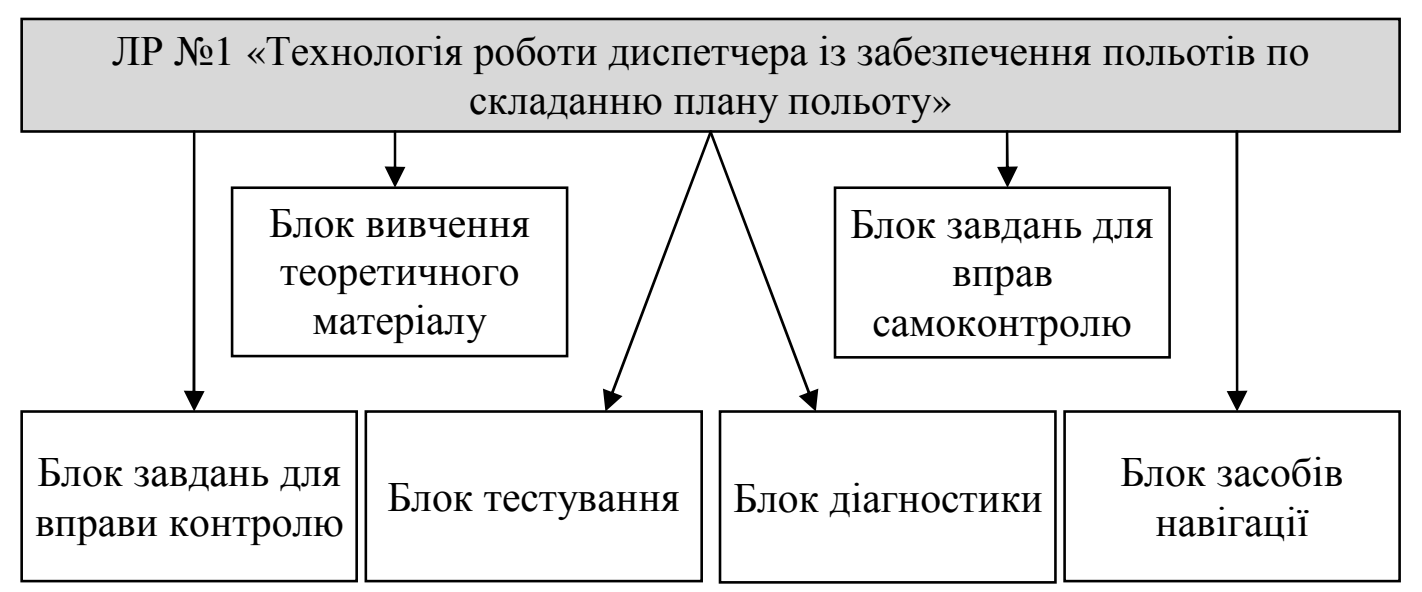

\section{Рис 4. Схема реалізації електронного лабораторного практикуму}

Одним із основних моментів при створенні лабораторного практикуму була розробка методів контролю i оцінки результатів навчання. Для об'єктивного оцінювання успішності курсантів застосовувалася методика оцінки знань на основі рівнів засвоєння, що використовувалась у роботі [29].

У цій методиці характеристикою завдання є рівень засвоєння, для перевірки якого воно призначено. Завдання поділяються на п'ять груп, відповідних рівнів засвоєння: 
розуміння, упізнання, відтворення, застосування, творча діяльність. Для кожного завдання визначається набір істотних операцій. Під істотними розуміють ті операції, які виконуються на рівні, що перевіряється. Операції, що належать до більш низьких рівнів, до істотних не належать.

Для виставлення оцінки використовується коефіцієнт

$$
K_{\alpha}=\frac{P_{1}}{P_{2}} \cdot 100 \%
$$

де $\mathrm{P}_{1}$ - правильно виконаних істотних операцій в процесі тестування.

$\mathrm{P}_{2}$ - загальна кількість істотних операцій у тесті.

Під істотними розуміють ті операції, які виконуються на рівні, що перевіряється. Операції, що належать до більше низьких рівнів, до істотних не належать.

Виходячи з цього: $0 \leq K_{\alpha} \leq 1$.

Отже, рівень засвоєння навчального матеріалу може бути використаний для оцінювання якості знань у курсантів та виставлення оцінки. Пропонуються наступні критерії для оцінки, наведені в таблиці1:

Таблиия 1

\section{Критерії оцінювання засвосного матеріалу}

\begin{tabular}{|c|l|}
\hline$K_{\alpha}<0,7$ & незадовільно \\
\hline $0,7 \leq K_{\alpha}<0,8$ & задовільно \\
\hline $0,8 \leq K_{\alpha}<0,9$ & добре \\
\hline$K_{\alpha} \geq 0,9$ & відмінно \\
\hline
\end{tabular}

Оцінки виставляються за тестування та контрольну вправу.

Авторами розроблені керівництво користувача, що представлене в головному меню програми, кнопка «Інструкція користувачу» i методичні рекомендації 3 виконання Лабораторної роботи «Технологія роботи диспетчера із ЗП по складанню плану польоту».

Наступним кроком була розробка самого ЕЛП «План польоту», інтерфейс якого представлено на Рис. 5 - Рис. 7.

Функції і можливості, реалізовані у в ЕЛП «План польоту»:

- захист інформації від несанкціонованого доступу, розмежування прав доступу користувачів ЕЛП до його функцій і компонентів, надання інструкції для роботи з системою;

- забезпечення функції запуску і завершення роботи;

- забезпечення доступу до навчального матеріалу; здійснення навігації по змістовому наповненню;

- у ЕЛП зберігається інформація, необхідна для складання плану польоту: основний теоретичний матеріал, заповнені зразки FPL, електронні карти, аеронавігаційні документи тощо;

- можливість здійснення вхідного контролю (виконується на початку роботи 3 ЕЛП і необхідне для оцінювання початкової підготовленості курсанта 3 дисципліни), самоконтролю і підсумкового контролю;

- вибір вправи (самоконтролю або контролю), надання умов завдання курсанту;

- оцінювання результатів навчання курсанта;

- формування рекомендацій з подальшого навчання;

- збір і обробка відомостей про результати навчання, виведення даних оцінювання на екран в контрольній вправі і тестуванні; 
- результати оцінювання вхідного і контрольного тестування зберігаються у спеціальному файлі «MyTestStudent_Result»;

- можливість доповнення та коригування навчального матеріалу.

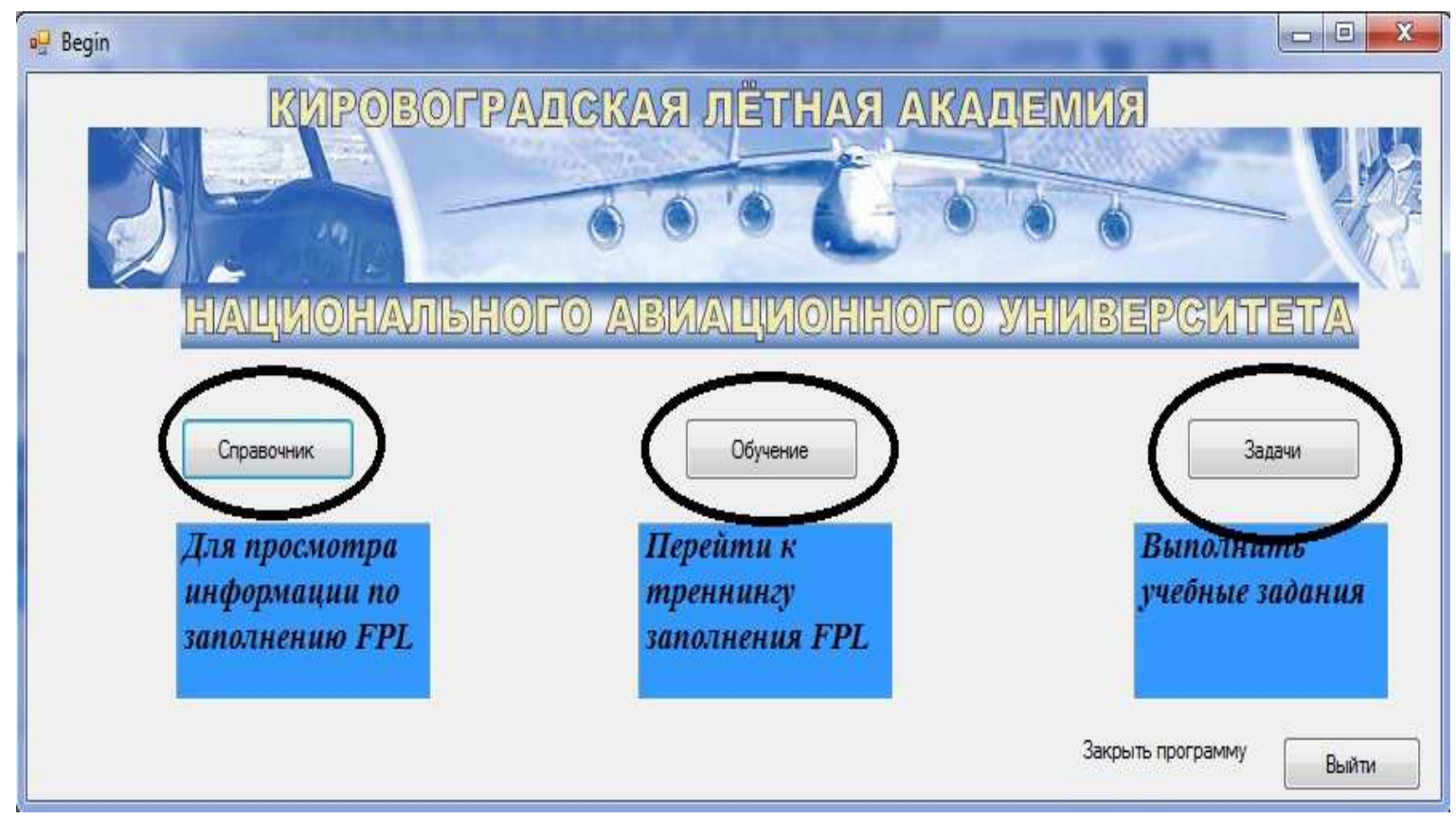

Рис. 5. Головне вікно електронного лабораторного практикуму «План польоту»

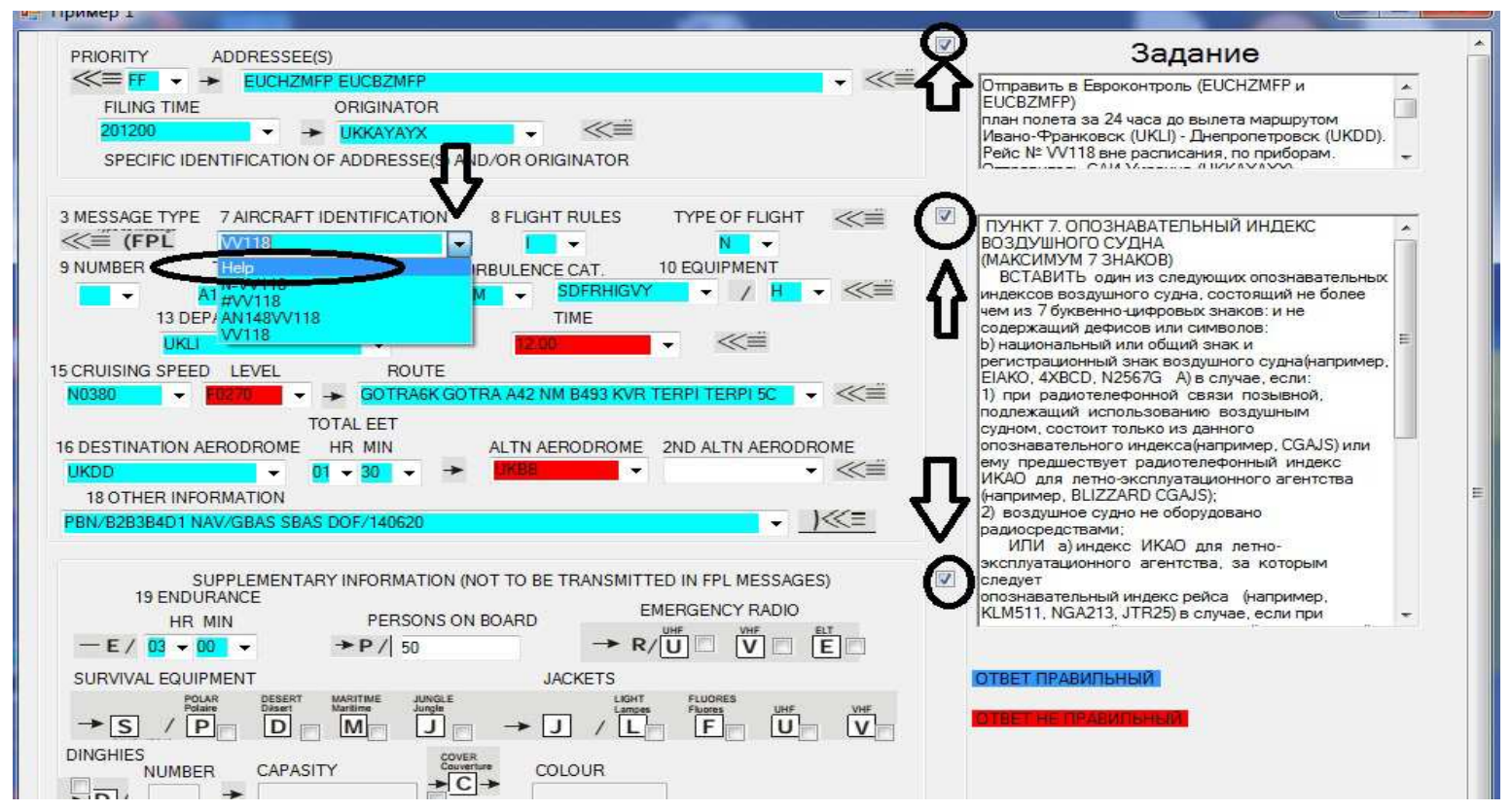

Рис. 6. Інтерфейс електронного лабораторного практикуму «План польоту» 


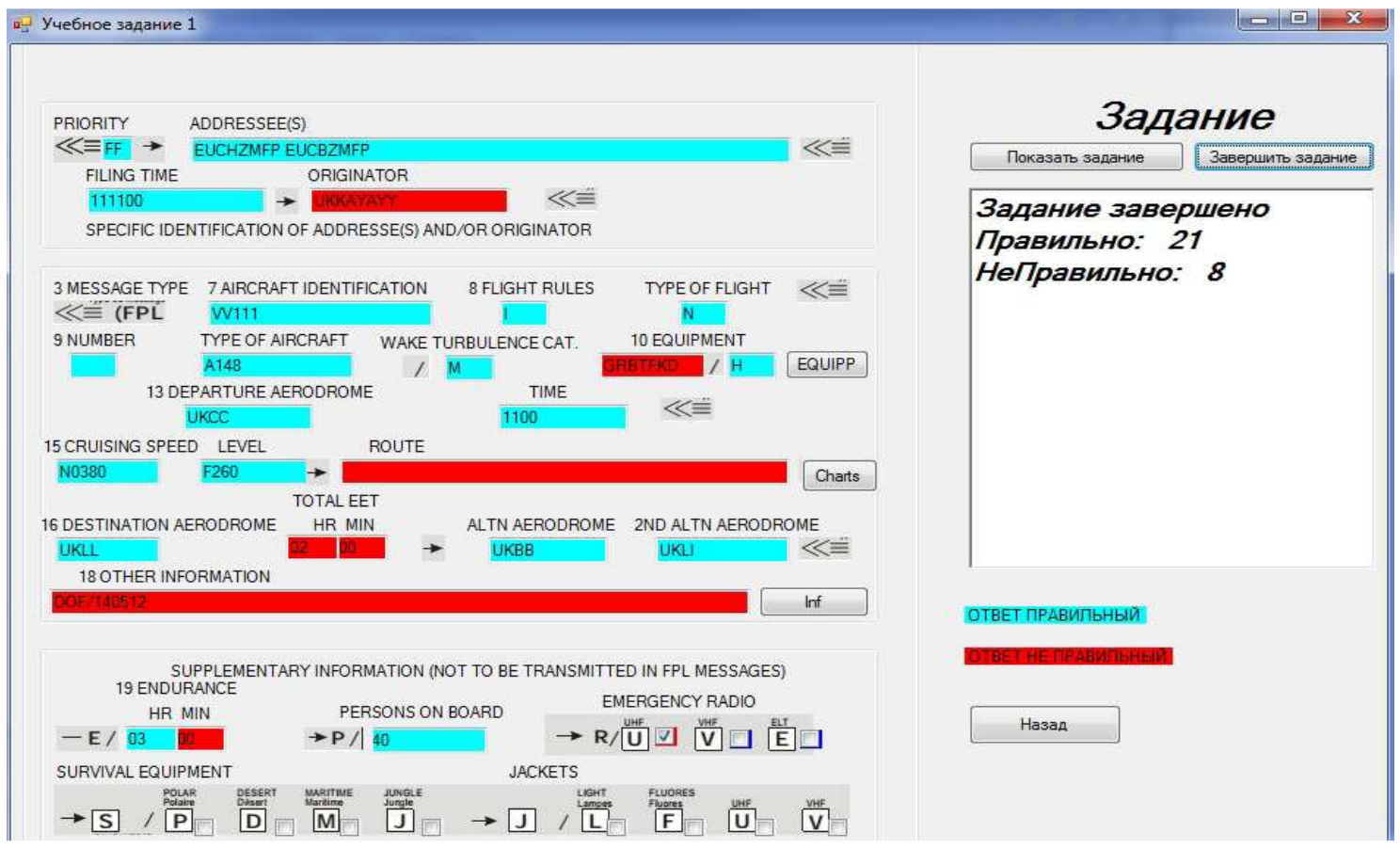

Рис. 7. Принциип роботи навчального завдання в електронному лабораторному практикумі «План польоту»

У дослідженні проводився короткочасний експеримент 3 апробації прототипу ЕЛП «План польоту» на базі Льотної академії Національного авіаційного університету за участю 10 викладачів кафедри інформаційних технологій, оскільки дана кафедра $є$ випусковою для курсантів спеціальності 272«Авіаційний транспорт» спеціалізації «Аеронавігаційне забезпечення і планування польотів».

Після перевірки працездатності практикуму респонденти були ознайомлені 3 інструкцією по заповненню анкети. У ній пропонувалось оцінити наявність реалізованих функцій у прототипі ЕЛП «План польоту» за трьома критеріями: технікотехнологічним, психолого-педагогічним та дизайн-критерієм. Кожен з критеріїв, своєю чергою, характеризується рядом показників.

Показники техніко-технологічного критерію:

1) наявність і якість захисту від несанкціонованих дій;

2) працездатність усіх заявлених функцій і можливостей ЕЛП;

3) наявність підсистем діагностування, попереджень; системи;

4) можливість продовження роботи за збоїв i відновлення працездатності

5) коректність функціонування ЕЛП одночасно з іншими засобами;

6) достатня швидкість реагування на запити користувачів;

7) простота, надійність і повнота інсталяції та деінсталяції установки;

8) низькі системні вимоги.

Показники психолого-педагогічного критерію:

1) доступність викладення навчального матеріалу;

2) наочність викладення навчального матеріалу;

3) забезпечення самостійності й активізації діяльності курсантів;

4) забезпечення систематичності і послідовності навчання;

5) реалізація можливостей комп'ютерної візуалізації навчальної інформації;

6) надання можливості тренувальних дій із засвоєння навчального матеріалу;

7) повнота надання довідкового матеріалу для успішного виконання вправ;

8) повнота змісту і відповідності навчальній програмі дисципліни «Планування і 
контроль за виконанням польотів» 3 теми «План польоту, правила його заповнення $\mathrm{i}$ подача до органів організації повітряного руху».

Аналіз можливостей застосування ЕЛП на різноманітних етапах навчання:

1) засвоєння нових знань;

2) засвоєння навичок і вмінь;

3) застосування знань, умінь і навичок;

4) узагальнення й систематизація знань;

5) перевірка і корекція знань, навичок, умінь;

6) комбіновані можливості;

7) засвоєння навичок, умінь, їх творчого застосування на практиці;

Показники дизайн-критерію:

1) простота и доступність інтерфейсу для курсантів;

2) достатній час реакції на відповідь або керуючий вплив;

3) відповідність маршрутів дій кнопкам «меню»;

4) наявність інструкції чи підказки;

5) зручність використання підказок, надписів, інструкції та інше;

6) наявність одноманітної, але контекстно залежної коригуючої реакції на змістові помилки;

7) зручність навігації по змістовному наповненню ЕЛП;

8) наявність і зручність роботи пошукової системи.

Аналіз функціональних можливостей ЕЛП з планування польотів здійснювався за допомогою критеріїв оцінки, представлених в анкеті. Варіанти відповідей передбачали «+» або «-». За наявності показників техніко-технологічного, психолого-педагогічного та дизайн-критерію ставився «+», за відсутності «-». Думка респондентів стосовно застосування електронного практикуму на певному етапі навчання враховувалася тільки знаком «+».

Якщо респондентами під час апробації прототипу даного електронного засобу навчання було виявлено як переваги, так і недоліки, це відзначалось у додаткових відомостях. Отже, оцінювались такі функції, реалізовані в прототипі ЕЛП «План польоту»:

- надання інструкції для роботи з системою;

- запуск і завершення роботи;

- забезпечення доступу до навчального матеріалу, надання i забезпечення взаємодії з ним; здійснення навігації по змістовому наповненню;

- зберігання інформації, необхідної для заповнення заявки: основний теоретичний матеріал, заповнені зразки заявок, електронні карти, аеронавігаційні документи та ін.;

- вибір вправи (самоконтролю або контролю), надання умов завдання курсанту;

- генерація тестових завдань;

- оцінювання результатів навчання курсанта;

- формування рекомендацій з подальшого навчання;

- збір і обробка даних про результати навчання, виведення даних оцінювання на екран у контрольній вправі і тестуванні;

- збереження результатів оцінювання вхідного й контрольного тестування в спеціальному файлі «MyTestStudent_Result»;

- доповнення й коригування навчального матеріалу

Результати експертної оцінки по представленим групам показників для кожного критерію оцінки ЕЛП «План польоту» розподілилися так:

За показниками техніко-технологічного критерію (Рис.8.): 
- повну наявність заявлених функцій ЕЛП з ПП за показниками №№1,2,4,5,6,7,8 відзначили $100 \%$ опитаних;

- відсутність реалізації 3 показника відзначили 100\% опитаних.

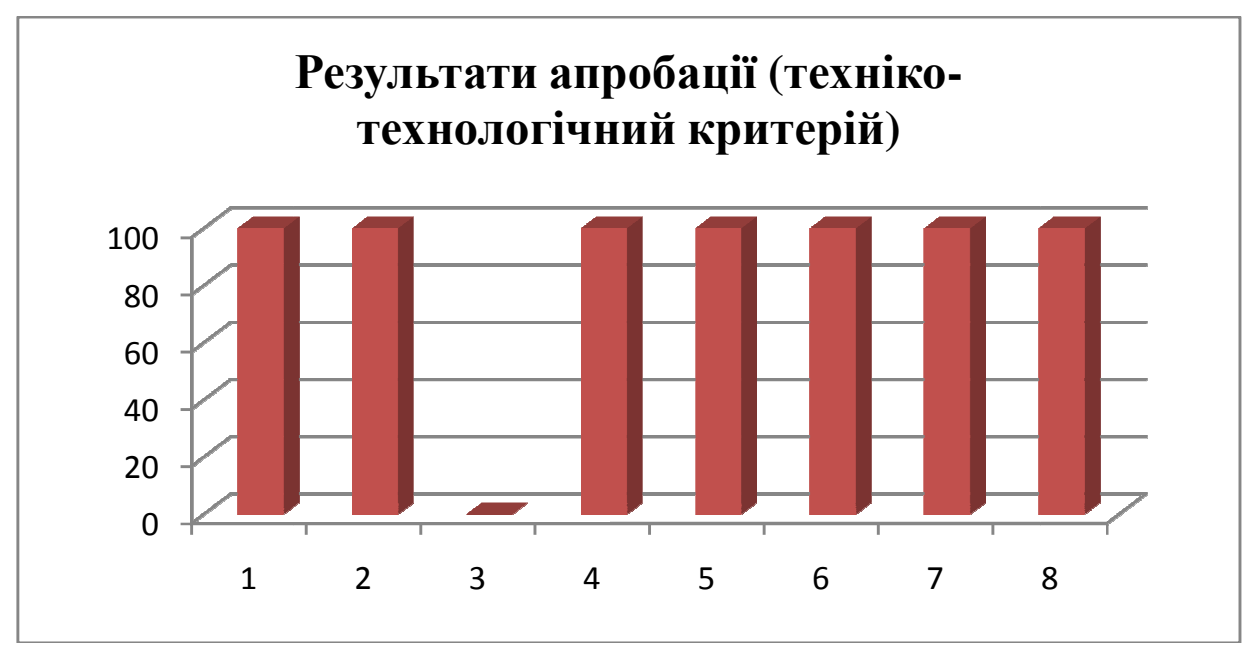

Рис.8. Аналіз і узагальнення отриманих результатів апробації за показниками техніко-технологічного критерію

За показниками психолого-педагогічного критерію 100\% опитаних заявили про повну наявність функцій електронного практикуму 3 планування польотів за показниками №№ 1,2,3,4,5,6,7,8. За показником №9 (Аналіз можливостей застосування ЕЛП з планування польотів на різноманітних етапах навчання) 100\% опитаних обрали варіант «застосування на комбінованих видах навчальних занять» (Рис.9.).

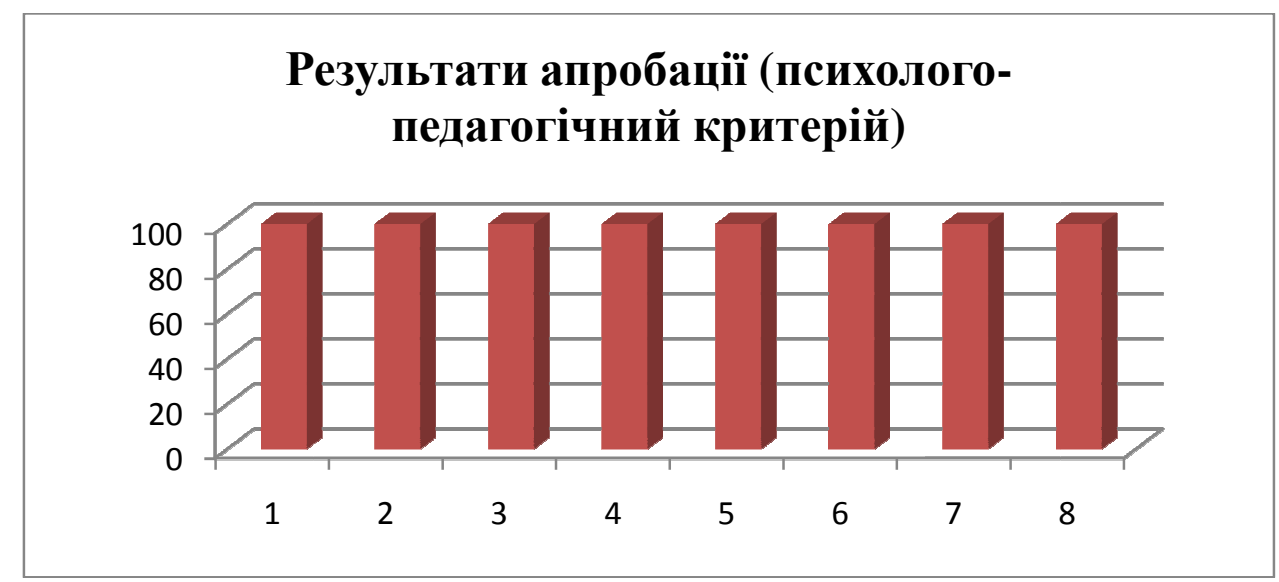

Рис.9. Аналіз і узагальнення отриманих результатів апробації за показниками психолого-педагогічного критерію

За показниками дизайн-критерію (Рис.10.):

- 100\% опитаних заявили про повну наявність функцій практикуму за показниками №№ 1,2,3,4,6;

- неповноту реалізації показника №5 відзначили 26\% (5 з 19) опитаних;

- неповноту реалізації показника №7 відзначили 5\% (1 з 19) опитаних;

- відсутність реалізації показника № 8 відзначили 100\% опитаних. 


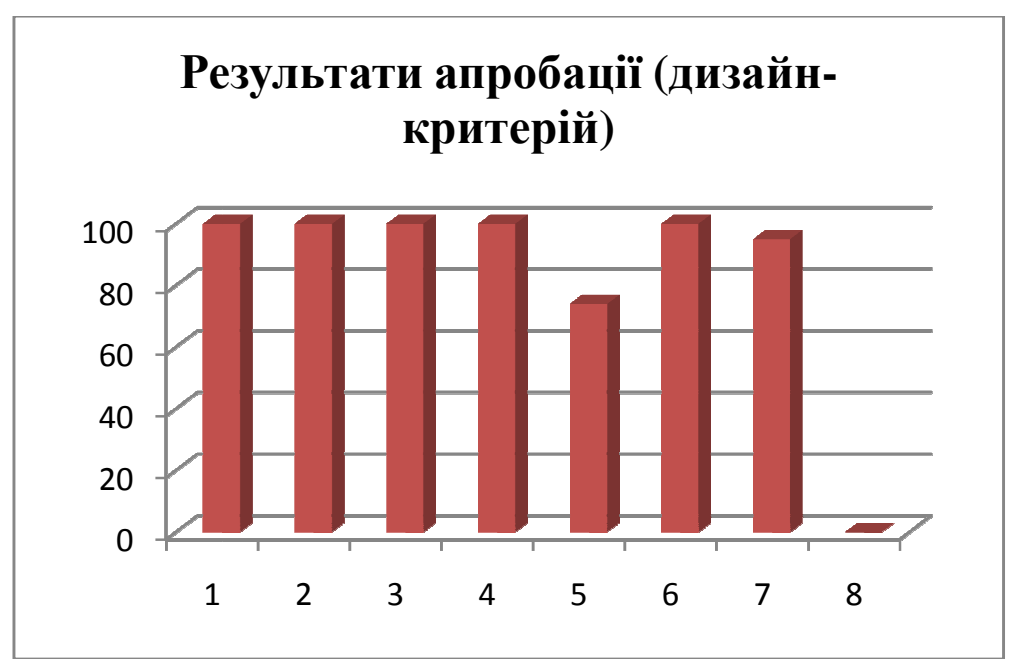

Рис.10. Аналіз і узагальнення отриманих результатів апробації за показниками дизайн-критерію

Оскільки показники №№ 1,2,4,5,6,7,8 техніко-технологічного критерію повністю реалізовані, то загалом відсоток реалізації техніко-технологічного критерію становить $\frac{7 \cdot 100 \%+0 \%}{8}=87,5 \%$.

Психолого-педагогічний критерій реалізовано повністю, тобто на $100 \%$.

Оскільки показники №№ 1,2,3,4,6 дизайн-критерію реалізовані повністю (100\%), показник №8 не реалізовано (0\%), а показники №5 і №7 реалізовані на 74\% і 95\% відповідно, то загальна реалізація дизайн-критерію становить $\frac{5 \cdot 100 \%+74 \%+95 \%+0 \%}{8}=83,6 \%$

Узагальнені результати апробації представлені на Рис.11.

\section{Узагальнені результати апробації ЕЛП "План польоту"}
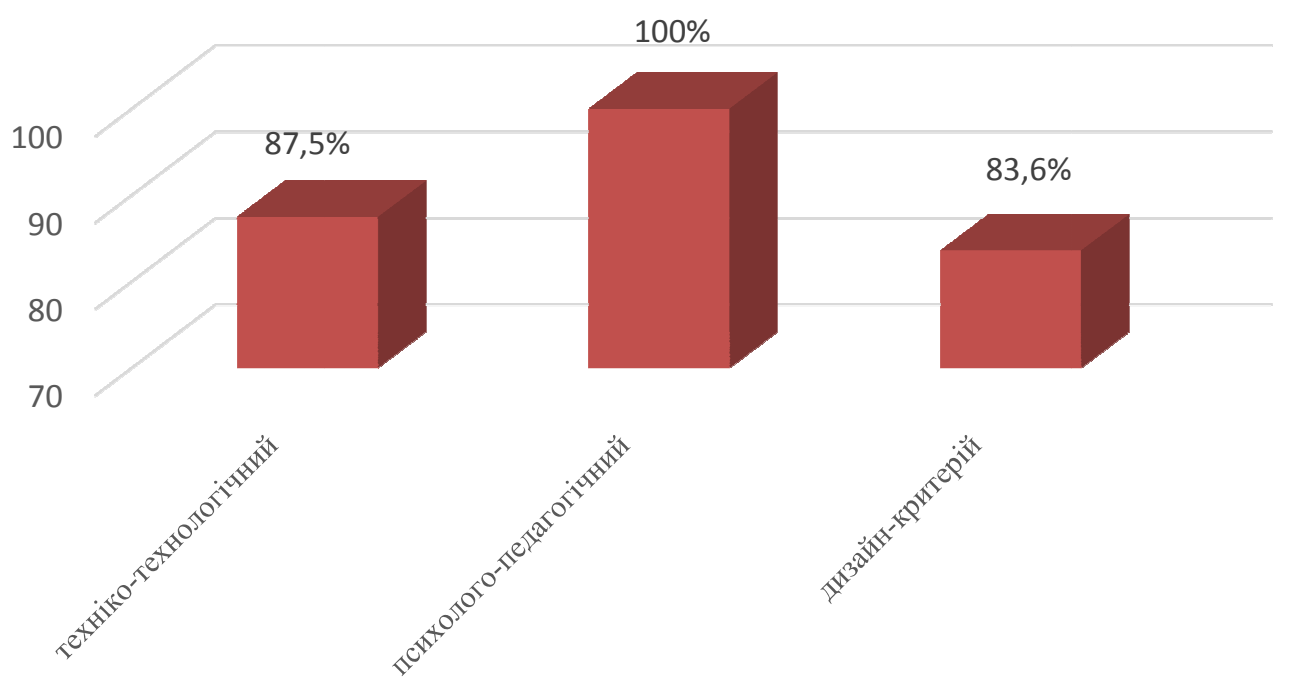

Рис.11. Аналіз і узагальнення отриманих результатів апробації електронного лабораторного практикуму «План польоту» 
Узгодженість експертів щодо критеріїв по кожній групі показників перевірялась методом експертного оцінювання [30].

Так, значення коефіцієнта аргументації для $i$-го експерта визначається за формулою:

$$
K_{i}^{A P \Gamma}=\frac{\sum_{j=1}^{n} \gamma_{j i}}{\sum_{j=1}^{n} \gamma_{j i}^{\max }}
$$

де $\gamma_{j i}$ - оцінка, відзначена по $i$-му варіанту $j$ - го джерела аргументації;

$\gamma_{j i}^{\max }$ - максимальна оцінка по $i$-му варіанту;

$n$ - кількість джерел аргументації в таблиці 2.

3 урахуванням того, що $\sum_{j=1}^{n} \gamma_{j i}^{\max }=1$, робоча формула має вигляд:

$$
K_{i}^{A P \Gamma}=\sum_{j=1}^{n} \gamma_{j i}
$$

При знаходженні $K^{A P \Gamma}$ береться до уваги:

- сумарне значення $K^{A P \Gamma}$ не повинно перевищувати 1 ;

- значенню $K^{A P \Gamma}=1$ відповідає високий ступінь впливу на думку експерта всіх джерел аргументації;

- значенню $K^{A P \Gamma}=0,8$ - середній ступінь впливу;

- значенню $K^{A P \Gamma}=0,5$ - низький ступінь впливу;

- значення коефіцієнта аргументації зменшується при переході від «виробничого досвіду» до «теоретичного аналізу» і від останнього до інших джерел аргументації.

Таблиия 2 Числові оцінки значимості вихідної інформації, відповідні до комбінацій джерел
аргументації з урахуванням їх впливу на думку експерта

\begin{tabular}{|l|c|c|c|}
\hline \multicolumn{1}{|c|}{ Джерело аргументації } & \multicolumn{3}{|c|}{ Ступінь впливу джерел на думку } \\
\cline { 2 - 4 } & високий & середній & низький \\
\hline Результати теоретичного аналізу & 0,30 & 0,20 & 0,10 \\
\hline Виробничий досвід & 0,25 & 0,20 & 0,10 \\
\hline Науковий досвід & 0,25 & 0,20 & 0,10 \\
\hline $\begin{array}{l}\text { Результати узагальнення робіт вітчизняних } \\
\text { авторів }\end{array}$ & 0,05 & 0,05 & 0,05 \\
\hline $\begin{array}{l}\text { Результати узагальнення робіт закордонних } \\
\text { авторів }\end{array}$ & 0,05 & 0,05 & 0,05 \\
\hline $\begin{array}{l}\text { Особисте знайомство зі станом справ за } \\
\text { кордоном }\end{array}$ & 0,05 & 0,05 & 0,05 \\
\hline Інтуїція & 0,05 & 0,05 & 0,05 \\
\hline
\end{tabular}


Ступінь поінформованості експерта в обговорюваних питаннях обраховується коефіцієнтом поінформованості $K^{I H \Phi}$, що відповідає формалізованим відомостям про поінформованість експерта по кожному з обговорюваних питань.

Чисельне значення даного коефіцієнта визначається шляхом підсумовування зазначених і-м експертом у комірках таблиці 2 чисел.

Таблиия 3

Числові кваліфікаційні оцінки відповідно до різних ступенів поінформованості експерта

\begin{tabular}{|c|c|c|c|c|c|c|c|c|}
\hline \multirow{2}{*}{$\begin{array}{c}\text { Стаж роботи } \\
\text { в області ПР }\end{array}$} & $\begin{array}{c}\leq 3 \\
\text { років }\end{array}$ & $\begin{array}{c}4 \\
\text { роки }\end{array}$ & $\begin{array}{c}5 \\
\text { років }\end{array}$ & $\begin{array}{c}6 \\
\text { років }\end{array}$ & $\begin{array}{c}7 \\
\text { років }\end{array}$ & $\begin{array}{c}8 \\
\text { років }\end{array}$ & $\begin{array}{c}9 \\
\text { років }\end{array}$ & $\geq 10$ років \\
\cline { 2 - 9 } & 0,13 & 0,355 & 0,4 & 0,45 & 0,5 & 0,55 & 0,6 & 0,65 \\
\hline
\end{tabular}

\begin{tabular}{|c|c|c|c|}
\hline $\begin{array}{c}\text { Наявність } \\
\text { наукового } \\
\text { ступеня i }\end{array}$ & $\begin{array}{c}\text { Доктор наук, } \\
\text { професор }\end{array}$ & $\begin{array}{c}\text { Кандидат наук, } \\
\text { доцент }\end{array}$ & Немає \\
\cline { 2 - 4 } вченого & & & 0,00 \\
звання в \\
галузі ПР
\end{tabular}

\begin{tabular}{|c|c|c|c|c|}
\hline $\begin{array}{c}\text { Наявність } \\
\text { наукових } \\
\text { праць в } \\
\text { галузі ПР }\end{array}$ & Монографія & $\begin{array}{c}\text { Патент, } \\
\text { АС }\end{array}$ & Статті & Алгоритми, програми \\
\cline { 2 - 5 } & 0,70 & 0,60 & 0,45 & 0,30 \\
\hline
\end{tabular}

\begin{tabular}{|c|c|c|c|c|}
\hline $\begin{array}{c}\text { Науково- } \\
\text { організаційна } \\
\text { робота }\end{array}$ & $\begin{array}{c}\text { Керівник } \\
\text { комплексу } \\
\text { робіт }\end{array}$ & $\begin{array}{c}\text { Керівник } \\
\text { однієї } \\
\text { роботи }\end{array}$ & $\begin{array}{c}\text { Учасник } \\
\text { виконання } \\
\text { декількох } \\
\text { робіт }\end{array}$ & $\begin{array}{c}\text { Учасник виконання } \\
\text { однієї роботи }\end{array}$ \\
\cline { 2 - 5 } & 0,60 & 0,50 & 0,30 & 0,10 \\
\hline
\end{tabular}

\begin{tabular}{|c|c|c|c|c|}
\hline $\begin{array}{c}\text { Участь у } \\
\text { конференціях } \\
\text { i семінарах в } \\
\text { галузі ПР }\end{array}$ & $\begin{array}{c}\text { Міжнародні } \\
\text { конференції і } \\
\text { симпозіуми }\end{array}$ & $\begin{array}{c}\text { Всеукраїнські } \\
\text { конференції й } \\
\text { симпозіуми }\end{array}$ & $\begin{array}{c}\text { Галузеві } \\
\text { конференції й } \\
\text { семінари }\end{array}$ & $\begin{array}{c}\text { Конференції } \\
\text { організацій і } \\
\text { підприємств }\end{array}$ \\
\hline
\end{tabular}

Якщо поінформованість експертів оцінюється за запитаннями в межах наведеної таблиці 3, то величина коефіцієнта $K^{I H \Phi}$ для і-го експерта визначається за формулою:

$$
K_{i}^{I H \Phi}=\frac{\sum_{v=1}^{5} \varphi_{v i}}{\sum_{v=1}^{5} \varphi_{v}^{\max }}
$$

де $\varphi_{v i}$ - числова кваліфікаційна оцінка $i$-го експерта по $v-\check{u}$ ознаці поінформованості; 
$\varphi_{v}^{\max }$ - максимальна оцінка по $v-u ̈$ ознаці поінформованості.

3 урахуванням того, що $\sum_{v=1}^{5} \varphi_{v}^{\max }=3,35$, робоча формула має вигляд:

$$
K_{i}^{I H \Phi}=\frac{\sum_{v=1}^{5} \varphi_{v i}}{3,35}
$$

Коефіцієнт компетентності $i$-го експерта визначається як добуток коефіцієнтів аргументації та поінформованості, тобто: $K_{i}^{K O M \Pi}=K_{i}^{A P \Gamma} \cdot K_{i}^{I H \Phi}$

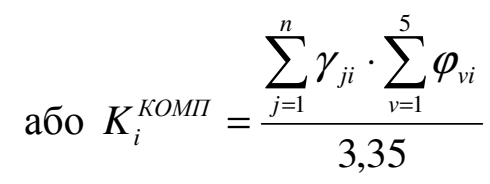

Репрезентативність експертної групи в цілому оцінюється середньою арифметичною величиною компетентності експертів:

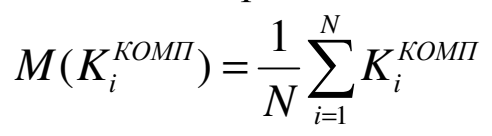

де $N$ - кількість експертів.

Експертна група вважається репрезентативною за умови:

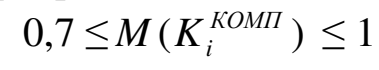

\begin{tabular}{|c|c|c|}
\hline $\begin{array}{c}\text { Розрахований коефіцієнт } \\
\text { аргументації для кожного і- } \\
\text { го експерта за формулою } \\
\text { (2) } \\
\end{array}$ & $\begin{array}{c}\text { Розрахований коефіцієнт } \\
\text { поінформованості для } \\
\text { кожного і-го експерта за } \\
\text { формулою (4) }\end{array}$ & $\begin{array}{c}\text { Розрахований коефіцієнт } \\
\text { компетентності для } \\
\text { кожного і-го експерта за } \\
\text { формулою (6) }\end{array}$ \\
\hline$K_{1}^{A P \Gamma}=0,85$ & $K_{1}^{O C B}=\frac{0,65}{0,65}=1$ & 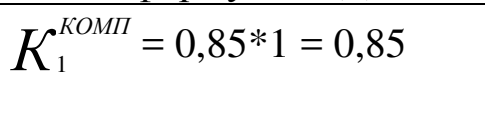 \\
\hline$K_{2}^{A P \Gamma}=0,7$ & $K_{2}^{O C B}=\frac{0,65}{0,65}=1$ & $K_{2}^{\text {КОМП }}=0,7 * 1=0,7$ \\
\hline$K_{3}^{A P \Gamma}=0,85$ & $K_{3}^{O C B}=\frac{0,45}{0,65}=0,69$ & $K_{3}^{\text {КOMI }}=0,85^{*} 0,69=0,59$ \\
\hline$K_{4}^{A P \Gamma}=0,85$ & $K_{4}^{O C B}=\frac{0,6}{0,65}=0,92$ & $K_{4}^{\text {КОМП }}=0,85^{*} 0,92=0,78$ \\
\hline$K_{5}^{A P \Gamma}=0,8$ & $K_{5}^{O C B}=\frac{0,55}{0,65}=0,85$ & $K_{5}^{\text {KOMI }}=0,8 * 0,85=0,68$ \\
\hline$K_{6}^{A P \Gamma}=0,8$ & $K_{6}^{O C B}=\frac{0,5}{0,65}=0,77$ & $K_{6}^{\text {KOMI }}=0,8^{*} 0,77=0,62$ \\
\hline
\end{tabular}

\section{Розраховані коефіцієнти для кожного експерта}




\begin{tabular}{|c|c|c|}
\hline$K_{7}^{A P \Gamma}=1,0$ & $K_{7}^{O C B}=\frac{0,6}{0,65}=0,92$ & $K_{7}^{\text {КОMП }}=1 * 0,92=0,92$ \\
\hline$K_{8}^{A P \Gamma}=0,7$ & $K_{8}^{O C B}=\frac{0,5}{0,65}=0,77$ & $K_{8}^{\text {KOMП }}=0,7^{*} 0,77=0,54$ \\
\hline$K_{9}^{A P \Gamma}=0,85$ & $K_{9}^{O C B}=\frac{0,55}{0,65}=0,85$ & $\begin{array}{l}K_{9}^{\text {КОМП }}=0,85^{*} 0,85= \\
0,7225\end{array}$ \\
\hline$K_{10}^{A P \Gamma}=1,0$ & $K_{10}^{O C B}=\frac{0,4}{0,65}=0,62$ & 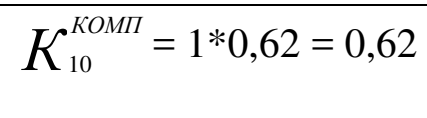 \\
\hline
\end{tabular}

Репрезентативність групи експертів розрахована за формулою (7):

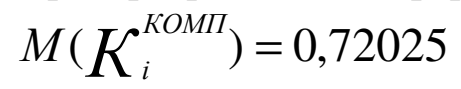

Отже, група експертів $є$ репрезентативною та може висловлювати думку більшості.

Складемо матрицю групових переваг для групи експертів $(\mathrm{m}=10)$ за показниками техніко-технологічного критерію $w_{i}$ та визначимо узгодженість думки експертів щодо наявності чи відсутності цих показників у розробленому практикумі.

Таблиия 5

Матриця групових переваг показників техніко-технологічного критерію розробленого електронного лабораторного практикуму «План польоту»

\begin{tabular}{|c|c|c|c|c|c|c|c|c|}
\hline Експерт & $\mathrm{w}_{1}$ & $\mathrm{w}_{2}$ & $\mathrm{w}_{3}$ & $\mathrm{w}_{4}$ & $\mathrm{~W}_{5}$ & $\mathrm{w}_{6}$ & $\mathrm{w}_{7}$ & $\mathrm{w}_{8}$ \\
\hline 1 & 2 & 3 & 1 & 4 & 6 & 5 & 7 & 8 \\
\hline 2 & 1 & 2,5 & 2,5 & 5 & 8 & 4 & 6 & 7 \\
\hline 3 & 3 & 1 & 2 & 6 & 5 & 4 & 8 & 7 \\
\hline 4 & 2 & 2 & 2 & 5 & 6 & 4 & 8 & 7 \\
\hline 5 & 2 & 3 & 1 & 4 & 6 & 5 & 7 & 8 \\
\hline 6 & 2 & 1 & 3 & 4 & 6 & 5 & 7 & 8 \\
\hline 7 & 2 & 3 & 1 & 4 & 6 & 5 & 8 & 7 \\
\hline 8 & 2 & 2 & 4 & 5 & 8 & 2 & 6 & 7 \\
\hline 9 & 1 & 3 & 3 & 5 & 6 & 3 & 7 & 8 \\
\hline 10 & 2 & 4 & 2 & 6 & 5 & 2 & 8 & 7 \\
\hline$R_{c p_{i}}$ & 1,9 & 2,45 & 2,15 & 4,8 & 6,2 & 3,9 & 7,2 & 7,4 \\
\hline$R_{z p_{i}}^{\prime}$ & 1 & 3 & 2 & 5 & 6 & 4 & 7 & 8 \\
\hline$Д_{i}$ & 0,32 & 0,91 & 1,002 & 0,62 & 1,067 & 1,433 & 0,62 & 0,267 \\
\hline$\sigma_{i}$ & 0,57 & 0,96 & 1,001 & 0,789 & 1,033 & 1,2 & 0,789 & 0,52 \\
\hline$v_{i}, \%$ & 29,88 & 39,02 & 46,57 & 16,4 & 16,66 & 30,7 & 10,96 & 6,98 \\
\hline
\end{tabular}

Визначимо думку групи експертів (середню):

$$
R_{c p}=\frac{\sum_{\mathrm{I}=1}^{m} R_{\mathrm{I}}}{m}
$$

Для кожної процедури

$R_{c p}$. Наприклад, для першої вимоги:

обрахуємо

значення 


$$
R_{c p 1}=\frac{2+1+3+2+2+2+2+2+1+2}{10}=1,9
$$

Доведемо узгодженість думки групи експертів щодо наявності в розробленому ЕЛП усіх заявлених показників техніко-технологічного критерію. Для цього обчислимо дисперсію Д, середнє квадратичне відхилення та коефіцієнт варіації. Якщо коефіцієнт варіації $v \leq 33 \%$, то думка експертів узгоджена.

Дисперсія для кожної вимоги:

$$
Д_{\mathrm{I}}=\frac{\sum_{\mathrm{I}=1}^{m}\left(R_{z p}-R_{\mathrm{I}}\right)^{2}}{m-1}
$$

Середнє квадратична відхилення обчислюється за формулою:

$$
\sigma_{\mathrm{I}}=\sqrt{Д_{\mathrm{I}}}
$$

Визначимо коефіцієнт варіації для кожної процедури:

$$
v_{\mathrm{I}}=\frac{\sigma_{\mathrm{I}}}{R_{z p \mathrm{I}}} \bullet 100 \%
$$

Тож коефіцієнт варіації $v \leq 33 \%$ вказує, що думка експертів стосовно оцінки наявності показників №№1,4,5,6,7,8 співпадає. Для вимог №№2,3 думка експертів не узгоджена. Оскільки для шести вимог коефіцієнт варіації $<33 \%$, то можна вважати думку експертів $\left(R_{\text {гp }}\right)$ за значущістю процедур узгодженою та підпорядкованою закону нормального розподілу випадкових величин.

Для оцінки узгодженості експертів за всіма вимогами скористаємось коефіцієнтом конкордації за Кендаллом, що розраховується за формулою:

$$
W=\frac{12 S}{m^{2}\left(n^{2}-n\right)},
$$

де $\mathrm{S}$ - сума квадратів різниць (відхилень)

$$
S=\sum_{i=1}^{n}\left\{\sum_{j=1}^{m} x_{i j}-a_{i j}\right\}^{2}
$$

$a_{i j}$-середнє значення для сумарних рангів ряду.

$$
a_{i j}=\frac{1}{2} m(n+1)
$$

Таблиия 4

\section{Підсумок однакових рангів}

\begin{tabular}{|l|l|l|l|l|l|l|l|l|l|l|}
\hline експерт & w1 & w2 & w3 & w4 & w5 & w6 & w7 & w8 & $\begin{array}{c}\text { Кількість } \\
\text { однакових } \\
\text { рангів }\end{array}$ & \\
\hline 1 & 2 & 3 & 1 & 4 & 6 & 5 & 7 & 8 & 0 & \\
\hline 2 & 1 & 2,5 & 2,5 & 5 & 8 & 4 & 6 & 7 & 2 & 6 \\
\hline 3 & 3 & 1 & 2 & 6 & 5 & 4 & 8 & 7 & 0 & \\
\hline 4 & 2 & 2 & 2 & 5 & 6 & 4 & 8 & 7 & 3 & 24 \\
\hline 5 & 2 & 3 & 1 & 4 & 6 & 5 & 7 & 8 & 0 & \\
\hline 6 & 2 & 1 & 3 & 4 & 6 & 5 & 7 & 8 & 0 & \\
\hline 7 & 2 & 3 & 1 & 4 & 6 & 5 & 8 & 7 & 0 & \\
\hline 8 & 2 & 2 & 4 & 5 & 8 & 2 & 6 & 7 & 3 & 24 \\
\hline
\end{tabular}




\begin{tabular}{|l|l|l|l|l|l|l|l|l|l|l|}
\hline 9 & 1 & 3 & 3 & 5 & 6 & 3 & 7 & 8 & 3 & 24 \\
\hline 10 & 2 & 4 & 2 & 6 & 5 & 2 & 8 & 7 & 3 & 24 \\
\hline $\begin{array}{l}\text { сума } \\
\text { рангів }\end{array}$ & 19 & 24,5 & 21,5 & 48 & 62 & 39 & 72 & 74 & & 102 \\
\hline$a_{i j}$ & 45 & & & & & & & & & \\
\hline$S$ & 676 & 420,25 & 552,25 & 9 & 289 & 36 & 729 & 841 & 3552,5 & \\
\hline знаменник & 4115 & & & & & & & & & \\
\hline$W$ & 0,863305 & & & & & & & & & \\
\hline
\end{tabular}

Значущість отриманого коефіцієнта конкордації - 0,863305. Цей коефіцієнт виявився значущим (для рівня значущості 0,01 критичне значення становить 2,76 , а для рівня значущості 0,05 - 1,812). Отже, можна стверджувати, що думка експертів $\epsilon$ узгодженою, а результати експертної оцінки - достовірними.

\section{5. ВИСНОВКИ ТА ПЕРСПЕКТИВИ ПОДАЛЬШИХ ДОСЛІДЖЕНЬ}

Очевидно, що одним із шляхів вирішення проблеми вдосконалення професійної підготовки майбутніх диспетчерів із забезпечення польотів сьогодні $є$ розробка та впровадження електронних засобів навчання, які дозволяють імітувати професійну діяльність фахівців в різних умовах, дають можливість отримати теоретичні знання та набути необхідного практичного досвіду.

Електронний лабораторний практикум «План польоту» розроблено з урахуванням дидактичних, методичних, психологічних, ергономічних, технічних вимог до електронних навчальних засобів, а також специфічних вимог, зумовлених особливостями професійної підготовки операторів диспетчерів із забезпечення польотів. За допомогою розробленого електронного засобу навчання студенти виконують усі операції, необхідні диспетчеру із забезпечення польотів на робочому місці, проводиться тестування та виконується контрольна вправа 3 миттєво виставленою об'єктивною оцінкою; він дозволяє перевіряти знання, скористатись потрібним теоретичним матеріалом.

Водночас наголошуємо, що електронний лабораторний практикум «План польоту» - це лише прототип, який варто перевірити в реальних умовах та для більшої кількості респондентів. У разі отримання позитивного результату перспективи подальших досліджень вбачаємо в розробці науково-методичного забезпечення по практикуму «План польоту» (методичні вказівки до виконання лабораторних робіт по складанню плану польоту, форма звіту курсантів 3 виконання лабораторних робіт тощо) із подальшим упровадженням практикуму в навчальний процес.

Окремого дослідження може потребувати подальша розробка інтерфейсу електронного лабораторного практикуму «План польоту»:

- удосконалення блоку діагностики (контроль і оцінювання) курсантів (візуалізація помилок курсанта під час тестування i заповнення бланка заявки; візуалізація текстової і графічної успішності курсантів);

-доповнення блоку вправ для самоконтролю.

\section{СПИСОК ВИКОРИСТАНИХ ДЖЕРЕЛ}

[1]. Е. В. Суркова и П. А. Климков,“Анализ ошибок диспетчера по обеспечению полетов”,Управління високошвидкісними рухомими об'єктами та професійна підготовка операторів складних систем: матеріали Міжнародної науково-практичної конференції, с. 220, 2012. 
[2]. В. Ю. Биков та ін., Розвиток теоретичних основ інформатизації освіти та практична реалізація інформаційно-комунікаційних технологій в освітній сфері Украӥни. Житомир, Україна: ЖДУ ім. І. Франка, 2019.

[3]. О.Ю.Буров, В. В. Камишин, Н. І. Поліхун та А. Т. Ашеров. Технологї̈ використання мережевих ресурсів для підготовки молоді до дослідницької діяльності: монографія. Київ, Україна: Інформаційні системи. 2012.

[4]. М. П. Шишкіна. Формування і розвиток хмаро орієнтованого освітньо-наукового середовища вищого навчального закладу: Монографія. Київ, Україна: УкрIНTЕI, 2015.

[5]. A. Gray, "The 10 skills you need to thrive in the Fourth Industrial Revolution" [Електронний ресурс]. Доступно: https://www.weforum.org/agenda/2016/01/the-10-skills-you-need-to-thrive-in-thefourthindustrial-revolution/. Дата звернення: Вересень 26, 2020.

[6]. В. Pernici, Special Topics in Information Technology [Електронний ресурс]. Доступно: https://link.springer.com/book/10.1007\%2F978-3-030-32094-2\#editorsandaffiliations. Дата звернення: Вересень 26, 2020.

[7]. М. І. Жалдак “Комп’ютерно-орієнтовані системи навчання - становлення і розвиток”, Науковий часопис Національного педагогічного університету імені М.П. Драгоманова. Серія 2: 15 комп'ютерно-орієнтовані системи навчання, №9(16), с. 3-9, 2010.

[8]. В. М. Мадзігон, “Дидактичні вимоги до електронних підручників”, Проблеми сучасного підручника, зб. наук. працьь. Вип. 10, №10, с. 4-7, 2010.

[9]. В.М.Дем’яненко, Г.П.Лаврентьєва., М.П.Шишкіна, “Методичні рекомендації щодо добору і застосування електронних засобів та ресурсів навчального призначення", Комп'ютер у школі та сім'ї, №1, с.44-48, 2013.

[10]. Т. Ф. Шмельова, Ю.В.Сікірда “Методика моделювання розвитку польотних ситуацій”, Матеріали 19-ої міжнар. конф. з автоматичного управління “Автоматика-2012” с. 124-125, 2628 вересня 2012 p.

[11]. Т. С. Плачинда, Р. М. Макаров, О. О. Чумак, “Тренажерна підготовка як складова формування надійності майбутніх авіаційних фахівців" [Електронний ресурс]. Доступно: http://pedagogyjournal.kpu.zp.ua/archive/2017/55/35.pdf. Дата звернення: Вересень 26, 2020.

[12]. О. М. Рева, “Рівень домагань авіадиспетчерів на показниках робочого навантаження”, Авіаційнокосмічна техніка і технологія : наук.-техн. ж., № 8 (105), с. 273-281, 2013.

[13]. П. Ш. Мухтаров, “Людський чинник в аеронавігації: рівні домагань авіадиспетчерів при оцінці бажаності між повітряними судами” [Електронний ресурс]. Доступно: //kma.ks.ua/ua/images/science/publications/2014/1_10/40.pdf. Дата звернення: Вересень 26, 2020.

[14]. R. I. R. Abeyratne Aviation Security: Legal and Regulatory Aspects [Електронний ресурс]. Доступно: https://www.twirpx.com/file/2872276/ Дата звернення: Вересень 26, 2020.

[15]. Doc 9859. “Руководство по управлению безопасностью полетов (РУБП)”, ИКАО, 2013 [Електронний peсурс]. Доступно: http://www.scac.ru/ru/wp-content/uploads/2016/DOC_9859_3.pdf Дата звернення: Вересень 26, 2020.

[16]. Doc 7192 - AN/857 Часть D-3. Сотрудник по обеспечению полетов/диспетчер. Международная организация гражданской авиации. Изд. второе. 2016.

[17]. М. И. Беляев, В. В. Гриншкун. и Г.А. Краснова,Технология создания электронных средств обучения [Електронний ресурс]. Доступно: http://uu.vlsu.ru/files/Tekhnologija_sozdanija_EHSO.pdf Дата звернення: 9 березня, 2020.

[18]. В. М. Вымятнин, В. П. Демкин и Г. В. Можаева, Мультимедиа-курсы: методология и технология разработки [Електронний ресурс]. Доступно: https://ido.tsu.ru/files/pub2002/7_2002_vum_dem_mozh.pdf Дата звернення: 9 березня, 2020.

[19]. Лекції з дисципліни Інформаційні технології в практиці наукових досліджень [Електронний pесурс]. Доступно: http://www.asbit.nuczu.edu.ua/files/oit/lessons/ITPND/lek_kurs.pdf Дата звернення: 9 березня, 2020.

[20]. С. Е. Важинський, Т. І. Щербак, Методика та організація наукових досліджень. Суми, Україна: СумДПУ імені А. С. Макаренка, 2016.

[21]. Ю. О. Жук, О. М. Соколюк, Н. П. Дементієвська та О. П. Пінчук, Організація навчальної діяльності у комп'ютерно орієнтованому навчальному середовищі: посібник, Київ, Україна: Педагогічна думка, 2012.

[22]. М. Р. Петрик, Моделювання програмного забезпечення. Тернопіль, Україна: Вид-во ТНТУ імені Івана Пулюя, 2015.

[23]. В. В. Сидоренко, Л. В. Константинова, Організація баз даних. Кропивницький, Україна: ЦНТУ, 2017.

[24]. А. Г. Гуралюк, О. В. Діденко та ін., Методичні рекомендації щзодо розроблення електронного підручника для професійнотехнічних навчальних закладів, Київ, Україна: ТОВ «НВП 
Поліграфсервіс», 2014.

[25]. Doc 7910 - Указатели (индексы) местоположения. Международная организация гражданской авиации. Изд. 131. 2013.

[26]. Doc $8643-$ Условные обозначения типов ВC. Международная организация гражданской авиации. Изд. 142. 2009.

[27]. Г. В. Табунщик, Т. І. Каплієнко та О. А. Петрова, Проектування та моделювання програмного забезпечення сучасних інформачійних систем, Запоріжжя, Україна: Дике Поле, 2016.

[28]. Опорний конспект лекцій 3 дисципліни “Аналіз вимог до програмного забезпечення", [Електронний ресурс]. Доступно: http://dspace.tneu.edu.ua/bitstream/ 316497/24190/1/конспект\%20лекцій.pdf Дата звернення: Вересень 26, 2020.

[29]. Н. Д. Асеева, "Тестовая диагностика в системе компьютерной профессиональной подготовки будущего специалиста (На примере военного вуза)", дис. канд. пед. наук, Н. Новгород, 2001.

[30]. К. В. Суркова, Г. С. Тимошенко, Теорія управління: метод.вказівки до практичних занять з теми: «Експертні методи прийняття рішень», Кіровоград, Україна: КЛА НАУ, 2013.

Матеріал надійшов до редакиї 18.03.2020 p.

\title{
РАЗРАБОТКА И ИСПОЛЬЗОВАНИЕ ЭЛЕКТРОННОГО ЛАБОРАТОРНОГО ПРАКТИКУМА «ПЛАН ПОЛЕТА» ДЛЯ ПОДГОТОВКИ ДИСПЕТЧЕРОВ ПО ОБЕСПЕЧЕНИЮ ПОЛЕТОВ
}

\author{
Тимошенко Анна Сергеевна \\ старший преподаватель кафедры информационных технологий \\ Летная академия Национального авиационного университета, г. Кропивницкий, Украина \\ ORCID ID 0000-0003-2411-497X \\ jaanti@ukr.net \\ Данилко Оксана Григорьевна \\ кандидат педагогических наук, доцент кафедры информационных технологий \\ Летная академия Национального авиационного университета, г. Кропивницкий, Украина \\ ORCID ID 0000-0002-7942-8012 \\ monyasolnce@gmail.com
}

Сагановская Лариса Анатольевна

старший преподаватель кафедры информационных технологий

Летная академия Национального авиационного университета, г. Кропивницкий, Украина

ORCID ID 0000-0002-2560-4383

lora-sag@ukr.net

Аннотация. Статья посвящена разработке электронного лабораторного практикума «лан
полета». Авторами рассмотрен вопрос о целесообразности и эффективности введения
электронных средств обучения в образовательный процесс, поскольку в авиационной среде
существует потребность в усовершенствовании существующи и создании новых
электронных средств обучения в области планирования полетов и обеспечения экипажей
воздушных судов необходимой информацией. В процессе исследования установлено, что не
существует электронных лабораторных практикумов по планированию полетов для
подготовки будущих диспетчеров по обеспечению полетов. Выделены этапы создания и
применения электронных средств обучения. На этапе проектирования и разработки
практикума создан алгоритм имитации профессиональной деятельности диспетчера по
обеспечению полетов, построено структурную схему процесса обучения будущих
специалистов, которая должна быть реализована в лабораторном практикуме. В результате
системного анализа сформулированы требования к электронному лабораторному
практикуму «План полета, представлена схема реализации компонентов практикума, а
также непосредственно разработан интерфейс электронного средства обучения «План
полета» с описанием всех его функций и возможностей. В ходе экспериментального
исследования, которое проводилось на базе Летной академии Национального авиационого
университета, выполнена оценка реализованных функций практикума по технико-
технологическому, психолого-педагогическому и дизайн-критерию. Сделан вывод о
целесообразности использования электронного лабораторного практикума по 
планированию полетов в учебном процессе, так как разработанное электронное средство обучения позволяет имитировать профессиональную деятельность диспетчеров по обеспечению полетов в различных условиях, дает возможность получить теоретические знания и приобрести практический опыт по выбранной теме, а следовательно, повысить качество профессиональной подготовки авиационных специалистов.

Ключевые слова: диспетчер по обеспечению полетов; планирование полетов; электронные средства обучения; электронный лабораторный практикум.

\title{
DEVELOPMENT AND USE OF THE ELECTRONIC LABORATORY WORKSHOP “FLIGHT PLAN" FOR THE FLIGHT OPERATOR MANAGERS TRAINING
}

\author{
Anna S. Tymoshenko \\ Senior Lecturer at Department of Information Technologies \\ Flight Academy of National Aviation University, Kropyvnytsky, Ukraine \\ ORCID ID 0000-0003-2411-497X \\ jaanti@ukr.net \\ Oksana G. Danylko \\ $\mathrm{PhD}$ of Pedagogical Sciences, Associate Professor at Department of Information Technologies \\ Flight Academy of National Aviation University, Kropyvnytsky, Ukraine \\ ORCID ID 0000-0002-7942-8012 \\ monyasolnce@gmail.com
}

Larysa A. Saganovska

Senior Lecturer at Department of Information Technologies

Flight Academy of National Aviation University, Kropyvnytsky, Ukraine

ORCID ID 0000-0002-2560-4383

lora-sag@ukr.net

\begin{abstract}
The article deals with the development of an electronic laboratory workshop "Flight Plan". The authors consider the feasibility and effectiveness of introducing electronic training aids into the educational process, since in the aviation environment there is a need to improve existing and create new electronic training aids in the field of flight planning and providing aircraft crews with the necessary information. The study finds that there is no electronic laboratory flight planning workshop to train future flight controllers. The stages of the creation and use of electronic learning tools are highlighted. At the design and development stage of the workshop, an algorithm was created to simulate the professional activities of the flight operator managers, a block diagram of the training process for future specialists was built, which should be implemented in a laboratory workshop. As a result of a system analysis, the requirements for the electronic laboratory practice "Flight Plan" are formulated, a diagram of the implementation of the components of the practice is presented, and the interface of the electronic training tool "Flight Plan" with the description of all its functions and capabilities is directly developed. In the course of an experimental study, which was carried out on the basis of Flight Academy of National Aviation University, the implemented functions of the practice were evaluated according to technical, technological, psychological, pedagogical, and design criteria. It is concluded that it is advisable to use electronic laboratory practice on flight planning in the educational process, since the developed electronic training tool allows you to simulate the professional activities of flight operator managers in various conditions, makes it possible to gain theoretical knowledge and gain practical experience on a chosen topic, and therefore improve quality of professional training of aviation specialists.
\end{abstract}

Keywords: flight operator manager; flight planning; electronic learning tools; electronic laboratory workshop.

\section{REFERENCES (TRANSLATED AND TRANSLITERATED)}

[1]. E. V. Surkova and P. A. Klimkov,"Flight Manager Error Analysis",Management of High-Speed Moving Objects and Training of Complex Systems Operators: Proceedings of the International Scientific and 
Practical Conference, p. 220, 2012. (in Ukrainian)

[2]. V. Yu. Bykov et al., Development of theoretical bases of informatization of education and practical realization of information and communication technologies in the educational sphere of Ukraine. Zhytomyr, Ukraine: ZhSU named after I. Franko, 2019. (in Ukrainian)

[3]. O. Yu. Burov, V. V. Kamyshyn, N. I. Polikhun and A. T. Asherov. Technologies of using network resources to prepare young people for research: a monograph. Kyiv, Ukraine: Information systems. 2012 (in Ukrainian)

[4]. M. P. Shishkina, Formation and development of a cloud-oriented educational and scientific environment of a higher educational institution: Monograph. Kyiv, Ukraine: UkrINTEI, 2015. (in Ukrainian)

[5]. A. Gray, The 10 skills you need to thrive in the Fourth Industrial Revolution. [Online]. Available: https://www.weforum.org/agenda/2016/01/the-10-skills-you-need-to-thrive-in-the-fourthindustrialrevolution/. Accessed on: Sept. 26, 2020. (in English)

[6]. B. Pernici, Special Topics in Information Technology. [Online]. Available: https://link.springer.com/book/10.1007\%2F978-3-030-32094-2\#editorsandaffiliations. Accessed on: Sept. 26, 2020. (in English)

[7]. M. I. Zhaldak, "Computer-based learning systems - formation and development", Scientific Journal of the National Pedagogical University named after M.P. Drahomanov. Series 2: 15 computer-based learning systems, №9 (16), pp. 3-9, 2010. (in Ukrainian)

[8]. V. M. Madzigon, "Didactic requirements for electronic textbooks", Problems of a modern textbook, coll. Science. Works, vol. 10, no. 10, pp. 4-7, 2010. (in Ukrainian)

[9]. V. M. Demyanenko, G. P. Lavrentyeva, and M. P. Shishkina, "Methodical recommendations for the selection and use of electronic tools and resources for educational purposes", Computer in school and family, no. 1, pp. 44-48, 2013. (in Ukrainian)

[10]. T. F. Shmelyova, and Yu. V. Sikirda, "Methods for modeling the development of flight situations", Proceedings of the $19^{\text {th }}$ International. conf. On automatic control "Automation-2012", pp. 124-125, September 26-28, 2012. (in Ukrainian)

[11]. T. S. Plachynda, R. M. Makarov, and O. O. Chumak, Training training as a component of formation of reliability of future aviation specialists. [Online]. Available: http://pedagogyjournal.kpu.zp.ua/archive/2017/55/35.pdf. Accessed on: Sept. 26, 2020. (in Ukrainian)

[12]. O. M. Reva, "The level of claims of air traffic controllers on workload indicators", Aerospace engineering and technology: scientific-technical. Journal, no. 8 (105), pp. 273-281, 2013. (in Ukrainian)

[13]. P. Sh. Mukhtarov, The human factor in air navigation: the levels of claims of air traffic controllers in assessing the desirability between aircraft. [Online]. Available: //kma.ks.ua/ua/images/science/publications/2014/1_10/40.pdf. Accessed on: Sept. 26, 2020. (in Ukrainian)

[14]. R. I. R. Abeyratne, Aviation Security: Legal and Regulatory Aspects. [Online]. Available: https://www.twirpx.com/file/2872276/ Accessed on: Sept. 26, 2020. (in English)

[15]. Doc 9859. "Safety Management Manual (SMM)", ICAO, 2013 [Online]. Available http://www.scac.ru/ru/wp-content/uploads/2016/DOC_9859_3.pdf. Accessed on: Sept. 26, 2020. (in Russian)

[16]. Doc 7192 - AN / 857 Part D-3. Flight Officer / Dispatcher. International Civil Aviation Organization. Ed. the second one. 1998. (in Russian)

[17]. M. I. Belyaev, V. V. Grinshkun, and G. A. Krasnov, Technology of creation of electronic learning tools. [Online]. Available: http://uu.vlsu.ru/files/Tekhnologija_sozdanija_EHSO.pdf Accessed on: Mar. 9, 2020. (in Russian)

[18]. V. M. Vymyatnin, V. P. Demkin, and G. V. Mozhaeva, Multimedia courses: methodology and development technology. [Online]. Available: https://ido.tsu.ru/files/pub2002/7_2002_vum_dem_mozh.pdf Accessed on: Mar. 9, 2020. (in Russian)

[19]. Lectures on the discipline «Information technology in the practice of scientific research». [Online]. Available: http://www.asbit.nuczu.edu.ua/files/oit/lessons/ITPND/lek_kurs.pdf Accessed on: Mar. 9, 2020. (in Ukrainian)

[20]. S. E. Vazhynsky, and T. I. Scherbak, Methodology and organization of scientific research. Sumy, Ukraine: AS Makarenko Sumy State Pedagogical University, 2016. (in Ukrainian)

[21]. Yu. O. Zhuk, O. M. Sokolyuk, N. P. Dementievskaya and O. P. Pinchuk, Organization of educational activity in a computer-oriented learning environment: textbook, Kyiv, Ukraine: Pedagogical Thought, 2012. (in Ukrainian)

[22]. M. R. Petryk, Software modeling. Ternopil, Ukraine: Ivan Pulyuy TNTU Publishing House, 2015. (in Ukrainian)

[23]. V. V. Sidorenko, L. V. Konstantinova, Organization of databases. Kropyvnytskyi, Ukraine: CNTU, 2017. (in Ukrainian) 
[24]. A. G. Guralyuk, O. V. Didenko et al, Methodical recommendations for the development of an electronic textbook for vocational schools, Kyiv, Ukraine: LLC "SPE Poligrafservice", 2014. (in Ukrainian)

[25]. Doc 7910 - Location Pointers (Indexes). International Civil Aviation Organization. ” Ed. 131. 2009.(in Russian)

[26]. Doc 8643 - Symbols for aircraft types. International Civil Aviation Organization. Ed. 142. 2009. (in Russian)

[27]. G. V. Tabunshchyk, T. I. Kapliyenko and O. A. Petrova, Designing and modeling of software of modern information systems, Zaporizhzhya: Dyke Pole,Ukraine: 2016. (in Ukrainian)

[28]. Reference syllabus of lectures on the subject "Analysis of software requirements", [Online]. Available: http://dspace.tneu.edu.ua/bitstream/ 316497/24190/1/конспект\%20лекцій.pdf Accessed on: Sept. 26, 2020. (in Ukrainian)

[29]. N. D. Aseeva, "Test diagnostics in the system of computer training of a future specialist (On the example of a military university", dis.cand. ped sciences, N. Novgorod, 2001. (in Russian)

[30]. K. V. Surkova, and G. S. Tymoshenko, Management theory: methodical instructions for practical classes on the topic: "Expert methods of decision making", Kirovograd, Ukraine: KLA NAU, 2013. (in Ukrainian)

\section{(cc) EY-NC-SA}

ThisworkislicensedunderCreativeCommonsAttribution-NonCommercial-ShareAlike 4.0 InternationalLicense. 